Volume 50

\title{
The Problem of Singling out Religion
}

Michael W. McConnell

Follow this and additional works at: https://via.library.depaul.edu/law-review

\section{Recommended Citation}

Michael W. McConnell, The Problem of Singling out Religion, 50 DePaul L. Rev. 1 (2000)

Available at: https://via.library.depaul.edu/law-review/vol50/iss1/2

This Article is brought to you for free and open access by the College of Law at Digital Commons@DePaul. It has been accepted for inclusion in DePaul Law Review by an authorized editor of Digital Commons@DePaul. For more information, please contact digitalservices@depaul.edu. 


\title{
THE PROBLEM OF SINGLING OUT RELIGION
}

\author{
Michael W. McConnell*
}

\section{INTRODUCTION}

From the earliest days of the Republic, Americans have been debating whether the principle of free exercise entitles religious institutions or religiously motivated individuals to exemptions from generally applicable laws, or to other accommodations in order to alleviate the occasional conflict between the demands of faith and the demands of the state. The principal ground for the debate has been institutional: whether decisions about religious accommodation ought to be made by courts as a matter of constitutional right, or by legislatures as a matter of political discretion. During the drafting of the Bill of Rights by the First Congress, for example, the House of Representatives adopted, but the Senate rejected, James Madison's proposal to exempt those "religiously scrupulous of bearing arms" from compulsory militia service. ${ }^{1}$ Proponents stated that such a provision was necessary to "show the world that proper care is taken that the government may not interfere with the religious sentiments of any person." ${ }^{2}$ The principal ground of opposition was not that religious exemptions are unwarranted, but that the matter ought to be "left to the discretion of the Government." 3 Similarly, in early litigation under state constitutional equivalents of the Free Exercise Clause ${ }^{4}$ two courts interpreted their provisions as protecting religious claimants from the operation of generally applicable law (in cases involving priest-penitent confidentiality), ${ }^{5}$ while two other courts rejected such an interpretation. ${ }^{6}$ The latter courts concluded that requests for religious accommodation

* Presidential Professor, University of Utah College of Law.

1. The Complete Bill of Rights 173, 176 (Neil Cogan ed., 1997).

2. Id. at 190 (Mr. Boudinot).

3. Id. at 187 (Mr. Benson).

4. There was no litigation over the Free Exercise Clause in the early decades of the Republic. The first such case, Permoli v. New Orleans, 44 U.S. 589 (1845), held only that the First Amendment did not apply to the states.

5. People v. Philips, Court of General Sessions, City of New York (June 14, 1813), published in William Sampson, The Catholic Question in America (1813 and photo reprint 1974), excerpted in Privileged Communications to Clergymen, 1 CATH. Law. 199, 199-209 (1955); Commonwealth v. Cronin, 1 Q. L. J. 128 (Va. Richmond Cir. Ct. 1856). 
raise "considerations of policy" that should be addressed to the legislature. ${ }^{7}$

The United States Supreme Court has experienced the same tension between providing constitutional protection for religious exercise and deferring to the judgments of politically accountable institutions. In its 1990 decision overruling the prior doctrine of constitutional free exercise exemptions, Employment Division v. Smith ${ }^{8}$ the Court explained that religious accommodation, however desirable, must be left to the legislature: "to say that a nondiscriminatory religious-practice exemption is permitted, or even that it is desirable, is not to say that it is constitutionally required." As the author of the Smith opinion stated in a subsequent case, the question posed by the Free Exercise cases "is, quite simply, whether the people, through their elected representatives, or rather this Court, shall control the outcome of those . . cases." 10 Recently, Professor Eugene Volokh has made the interesting suggestion that religious exemptions should be decided on a "common law" model, in which decisions about specific conflicts are initially made by courts, subject to legislative revision. ${ }^{11}$

Each of these approaches presuppose that exemptions for religious activity are legitimate; the debate is over whether they should be constitutionally required. As the question of religious accommodation has returned to national and state legislatures, some commentators have posed a more radical question: not which institution should be vested with the responsibility of determining the balance between the exercise of religion and enforcement of the law, but whether it is legitimate for any body to exempt those engaged in the practice of religion from the regulatory burdens imposed on others. Opponents argue that to exempt individuals or institutions from generally applicable laws on the basis of religious objection, while leaving similarly situated individuals or institutions with secular objections to the law without a remedy, amounts to an unconstitutional "privileging" of religion over nonreligion, in violation of the Establishment Clause. ${ }^{12}$

6. Simon's Executors v. Gratz, 2 Pen. \& W. 412 (Pa. 1831); State v. Willson, 13 S.C.L. (2 McCord) 393 (1823). See also Commonwealth v. Drake, 15 Mass. 161 (1818) (rejecting claim for free exercise exemption on the facts).

7. Simon's Executors, 2 Pen. \& W. at 414.

8. 494 U.S. 872 (1990).

9. Id. at 890 .

10. City of Boerne v. Flores, 521 U.S. 507, 544 (1997) (Scalia, J., concurring).

11. Eugene Volokh, A Common-Law Model for Religious Exemptions, 46 UCLA L. REV. 1465 (1999). He suggests that this could be authorized by statute.

12. See, e.g., Frederick M. Gedicks, An Unfirm Foundation: The Regrettable Indefensibility of Religious Exemptions, 20 U. Ark. LitTle Rock L. Rev. 555 (1998); Stephen Gey, Why ls Religion Special?: Reconsidering the Accommodation of Religion under the Religion Clauses of the 
My thesis is that "singling out religion" for special constitutional protection is fully consistent with our constitutional tradition. In fact, it is virtually impossible to understand our tradition of the separation of church and state without recognizing that religion raises political and constitutional issues not raised by other institutions or ideologies. For this reason, the First Amendment contains a special provision governing the rights of free exercise and nonestablishment of religion: precisely because there are special constitutional rules applicable to religion.

This statement does not require that religion must always be treated differently. Obviously, there are many contexts in which the best means of ensuring that government may not control or direct religious practice is to require equal treatment of religion..$^{13}$ My thesis, rather, is that "religion-blindness" should not be treated as a general, or controlling, interpretation of the First Amendment. "Religion-blindness" is a tool, to be evaluated in particular cases according to the ultimate purposes of the Religion Clauses, to ensure that religion, as nearly as possible, is free from government control or influence, whether favorable or unfavorable. We ought to be discussing not whether religion should be "singled out," but how, when, and why it should be "singled out."

\section{Religious Exemptions: Current Law and The Critique}

Religion-specific exemptions are relatively common in our law, even after Smith. As a matter of constitutional rights, Smith left intact the requirement of strict scrutiny for laws burdening religious exercise in two contexts: where the burden is imposed on a case-by-case basis rather than pursuant to a generally applicable law, ${ }^{14}$ and where the burden to religious exercise is combined with a burden to some other constitutional right. ${ }^{15}$ Either category, if generously interpreted, could prove to be a substantial exception to the Smith rule. The first situation is easily satisfied because few statutes are genuinely applicable across the board, without exceptions and without consideration of individual cases. The second category is also easily overcome since any creative lawyer should be able to properly allege a burden (only a

First Amendment, 52 U. PITT. L. REv. 75 (1990); William Marshall, In Defense of Smith and Free Exercise Revisionism, 58 U. CH1. L. Rev. 308 (1991); Suzanna Sherry, Lee v. Weisman: Paradox Redux, 1992 Sup. CT. Rev. 123.

13. See Equal Treatment of Religion in a Pluralistic Society (Stephen V. Monsma, eds., 1998).

14. Smith, 494 U.S. at 884 .

15. $l d$. at $881-82$. 
burden and not an actual violation needs to be shown) on another constitutional right, such as property, speech, privacy, or association, in addition to the free exercise claim. In addition, Smith reaffirmed two specific categories of free exercise claims that have produced many cases regarding the internal governance of churches, ${ }^{16}$ and claims for unemployment compensation. ${ }^{17}$ The latter are especially controversial because the baseline for determining benefits and burdens is highly ambiguous. ${ }^{18}$ The unemployment cases hold that a worker who loses his or her job for religious reasons is constitutionally entitled to unemployment compensation, while workers who lose jobs for other important, but non-religious, reasons are not entitled to such compensation. The theory behind this rule is that when a state grants unemployment compensation to a worker who quits the job for "good cause," it is unconstitutional to refuse to recognize sincere religious reasons as "good cause." Under this doctrine, a worker who cannot work on Saturday for religious reasons is entitled to compensation, but not a worker who cannot work on Saturday in order to care for dependants. A worker who cannot work on armaments because of a religious objection to participation in war is entitled to compensation, but not a worker who quits because of powerful environmental objections to her employer's practices.

Aside from constitutional exemptions, there are statutes at the state and federal level designed to provide exemptions or accommodations to laws that burden religious exercise without a sufficient justification. The Religious Freedom Restoration Act (RFRA) ${ }^{19}$ is the most prominent of such statutes. Although the RFRA was invalidated by the Supreme Court as applied to state and local governments, ${ }^{20}$ it continues to apply to federal governmental action. ${ }^{21}$ The recently enacted Relig-

\footnotetext{
16. Id. at 877 .

17. Id. at 884 .

18. In Sherbert v. Verner, 374 U.S. 398 (1963), the Supreme Court held that a Saturday sabbatarian who lost her job when her employer, a textile manufacturing plant, assigned her to work on Saturday could not be denied unemployment compensation. The Court theorized that a denial of compensation would, in effect, penalize her for exercise of a constitutional right:

The ruling forces her to choose between following the precepts of her religion and forfeiting benefits, on the one hand, and abandoning one of the precepts of her religion in order to accept work, on the other hand. Governmental imposition of such a choice puts the same kind of burden upon the free exercise of religion as would a fine imposed against appellant for her Saturday worship.

$I d$. at 404 . While the result in Sherbert is defensible, it is far from clear that the Court's rationale is correct. See Michael W. McConnell \& Richard A. Posner, An Economic Approach to Issues of Religious Freedom, 56 U. CHI. L. Rev. 1, 35-45 (1989).

19. 42 U.S.C. $\$ \$ 2000 b b-2000 b b-4$ (1994).

20. City of Boerne, 521 U.S. 507 (1997).

21. In re Young, 141 F.3d 854 (8th Cir. 1998).
} 
ious Land Use and Institutionalized Persons $\mathrm{Act}^{22}$ provides protection for religious exercise threatened by land use and prison regulations. A number of states have enacted "state RFRAs," 23 and some state constitutions have been interpreted to provide similar protection. ${ }^{24}$ Under each of these enactments, burdens on religious exercise are subjected to independent judicial scrutiny that is not given to burdens on secular interests.

Even more common are statutes providing special treatment for religious concerns within the context of specific statutory schemes. A recent survey of federal and state law revealed that the terms "religion" or "religious" appear over 14,000 times, and religious exemptions appear in over 2,000 statutes. ${ }^{25}$ The study elaborated:

In the United States Code, for example, exemptions exist in food inspection laws for the ritual slaughter of animals, and for the preparation of food in accordance with religious practices. The tax laws contain numerous exemptions for religious groups and allow deductions for contributions to religious organizations. Federal copyright laws contain an exemption for materials that are to be used for religious purposes. Antidiscrimination laws, including Title VII, the Fair Housing Act, and the Aid to the Disabled Act, contain exemptions for religious organizations. Ministers are automatically exempt from compulsory military training and service. Aliens seeking asylum can do so on the grounds that they will suffer religious persecution if returned to their home countries and gambling laws contain an exemption for religious organizations. Those in the military may wear religious apparel while wearing their uniforms, subject to limitations imposed by the Secretary of Defense. And last, but certainly not least for purposes of this Note, federal drug laws contain an exemption for the religious use of peyote by members of the Native American Church. ${ }^{26}$

Even before Smith, legislative accommodations were far more important to the protection of religious exercise than the First Amendment. This fact is even more true today.

The Supreme Court has repeatedly held that religious accommodations are constitutionally permissible, even if not constitutionally re-

22. Religious Land Use and Institutionalized Persons Act of 2000, Pub. L. No. 106-274, (106 Stat. 2869).

23. See Volokh, supra note 11; Alan E. Brownstein, State RFRA Statutes and Freedom of Speech, 32 U.C. Davis L. Rev. 605 (1999).

24. See Daniel A. Crane, Beyond RFRA: Free Exercise of Religion Comes of Age in the State Courts, 10 St. Thomas L. Rev. 235 (1998).

25. See James E. Ryan, Note, Smith and the Religious Freedom Restoration Act: An Iconoclastic Assessment, 78 VA. L. Rev. 1407, 1445 (1992).

26. Id. at 1446 (footnotes omitted). 
quired.27 In Corporation of the Presiding Bishop of the Church of Jesus Christ of Latter-day Saints v. Amos, ${ }^{28}$ the Court held that "it is a permissible legislative purpose to alleviate significant governmental interference with the ability of religious organizations to define and carry out their religious missions." The Court noted that "[w]here, as here, government acts with the proper purpose of lifting a regulation that burdens the exercise of religion, we see no reason to require that the exemption come packaged with benefits to secular entities."29 Even in cases striking down religious accommodations, the Court has taken pains to explain that there was some specific defect in the law. In Board of Education of Kiryas Joel v. Grumet, ${ }^{30}$ for example, the Court explained that

we do not deny that the Constitution allows the State to accommodate religious needs by alleviating special burdens. Our cases leave no doubt that in commanding neutrality the Religion Clauses do not require the government to be oblivious to impositions that legitimate exercise of state power may place on religious belief and practice. $^{31}$

In Texas Monthly, Inc. v. Bullock, ${ }^{32}$ Justice Brennan, writing for a plurality of the Court, stated, "we in no way suggest that all benefits conferred exclusively upon religious groups or upon individuals on account of their religious beliefs are forbidden by the Establishment Clause unless they are mandated by the Free Exercise Clause." 33

The only cases which held to the contrary were two Vietnam-era draft cases in which the Court held that the term "religion" had to be extended to include deeply held secular beliefs. ${ }^{34}$ However, in those cases, the Court relied on the interpretation of a statute, and only Justice Harlan took the position that the Constitution forbids the singling out of religion.

Nonetheless, some lawyers, judges, and academics argue that it is unfair, and unconstitutional, to exempt religious believers or institutions from laws that their secular counterparts are required to obey.

27. For a discussion of the Supreme Court's doctrine of religious accommodation, see Michael W. McConnell, Accommodation of Religion, 1985 Sup. CT. REv. 1; Michael W. McConnell, Accommodation of Religion: An Update and a Response to the Critics, 60 Geo.WASH. L. Rev. 685 , 698-708 (1992); see also Thomas C. Berg, The New Attacks on Religious Freedom Legislation, And Why They Are Wrong, 21 Cardozo L. Rev. 415, 434-43 (1999).

28. 483 U.S. 327,335 (1987).

29. Id. at 338. See also Gillette v. United States, 401 U.S. 437 (1971); Zorach v. Clauson, 343 U.S. 306 (1952).

30. 512 U.S. 687 (1994).

31. Id. at 705 .

32. 489 U.S. 1 (1989)

33. Id. at $18 \mathrm{n} .8$ (emphasis in original).

34. Welsh v. United States, 398 U.S. 333 (1970); United States v. Seeger, 380 U.S. 163 (1965). 
These commentators claim that such "singling out" of religion for special protection violates the neutrality commanded of the Religion Clauses by "privileging" religion over nonreligion. Perhaps the most prominent advocate of this position is Justice John Paul Stevens.

In City of Boerne v. Flores, ${ }^{35}$ the Court considered the constitutionality of the RFRA, ${ }^{36}$ which provides federal civil rights protection for the exercise of religion, and only religion, when it is burdened by laws which lack a sufficiently compelling public purpose. The particular context of the case was the effort by the Catholic Church to resist the city's decision to designate one its buildings as a historic landmark, which would have prevented the Church from enlarging its sanctuary. While the majority invalidated the RFRA as applied to state and local government on the grounds of federalism, Justice Stevens wrote a concurring opinion in which he argued that, by "singling out" religion for special protections, the RFRA violated the Establishment Clause. Stevens wrote:

If the historic landmark on the hill in Boerne happened to be a museum or an art gallery owned by an atheist, it would not be eligible for an exemption from the city ordinances that forbid an enlargement of the structure. Because the landmark is owned by the Catholic Church, it is claimed that RFRA gives its owner a federal statutory entitlement to an exemption from a generally applicable, neutral civil law. Whether the Church would actually prevail under the statute or not, the statute has provided the Church with a legal weapon that no atheist or agnostic can obtain. This governmental preference for religion, as opposed to irreligion, is forbidden by the First Amendment. ${ }^{37}$

On its own terms, this argument is not very persuasive. To be sure, a museum or an art gallery owned by an atheist would not be eligible for an exemption under the RFRA, but neither would a museum or an art gallery owned by a Catholic, a Buddhist, or a Jew. The question under the RFRA is not who owns the building, but whether the building is used for the exercise of religion. Under this analysis, atheists are also protected when they preach or proclaim their religious views, or seek to carry such views into practice. If the "historic landmark on the hill in Boerne" had been a meeting hall for the proclamation of the truths of atheism, it would have received the same protection under the RFRA that the Catholic Church received. (Atheists are protected against religious discrimination under Title VII, ${ }^{38}$ and pre-

35. 521 U.S. 507 (1997).

36. 42 U.S.C. $\$ \S 2000 \mathrm{bb}-2000 \mathrm{bb}-4$ (1994).

37. City of Boerne, 521 U.S. at 536-537 (1997) (Stevens, J., concurring).

38. See EEOC Complance Manual No. 915.003 (Aug. 7, 2000) ("Religious discrimination also includes discrimination against someone because s/he is an atheist."), citing Shapolia v. Los 
sumably, the RFRA would be similarly interpreted.) The problem (if there is a problem) is not that religious people or institutions are favored over atheists, but rather, that religious exercise, whether engaged in by Catholics, atheists, or anyone else, is protected, while worthy nonreligious activity by the same parties does not receive protection.

Scholars in law and related disciplines occasionally make a similar argument against the legitimacy of religious accommodation. ${ }^{39}$ For example, according to Isaac Kramnick and Laurence Moore, in their book, The Godless Constitution, religion should have "the same rights in the public sphere as General Motors, no more and no less." 40 In a similar vein, Professor Stephen Gey would interpret the Establishment Clause as "prohibiting accommodation of religiously mandated behavior beyond the scope of religious expression." 41 These arguments have radical implications. Since General Motors is subject to extensive regulation in almost every aspect of its operations, Kramnick and Moore's position suggests that the authority of the state to regulate or restrain the exercise of religion is substantial, and that free exercise rights essentially do not exist beyond the mere rational basis scrutiny that applies to the regulation of economic activity. Stephen Gey takes his position to the extreme of saying that a public school gym teacher should not be permitted to allow Hindu or Muslim girls to wear long pants with the gym uniform, where their religion would not permit them to expose their legs. ${ }^{42}$ Presumably this position also requires no accommodation to students for religious holidays, no recognition of the priest-penitent privilege, and no exemptions from sex discrimination laws for the all-male clergy.

Professors Christopher Eisgruber and Lawrence Sager have recently offered a more nuanced and attractive version of the claim that religious exercise may not be "singled out" for special protection that is not accorded to similar nonreligious activity. ${ }^{43}$ Eisgruber and Sager do not claim that government is forbidden to take steps to alleviate the special problems entailed by the conflict between faith and law.

Alamos National Laboratory, 773 F. Supp. 304, 305 (D.N.M. 1991), aff'd, Shapolia v. Church of Jesus Christ of Latter-Day Saints, 13 F.3d 406 (10th Cir. 1993).

39. See, e.g., supra note 12.

40. Issac Kramnick \& R. Laurence Moore, The Godless Constitution: The Case Against Religious Correctness 15 (1996).

41. Gey, supra, note 12 , at 182.

42. Id. at $183-84$.

43. They set forth their views in a series of articles, including The Vulnerability of Conscience: The Constitutional Basis for Protecting Religious Conduct, 61 U. CHI. L. Rev. 1245 (1994); Why the Religious Freedom Restoration Act Is Unconstitutional, 69 N.Y.U. L. REv. 437 (1994); and Unthinking Religious Freedom, 74 TEx. L. REv. 577 (1996). 
Rather, they insist that the measure of permissible religious accommodation is the accommodation accorded to comparable secular concerns. Eisgruber and Sager entitle this the principle of "equal regard," which "requires simply that government treat the deep, religiously inspired concerns of minority religious believers with the same regard as that enjoyed by the deep concerns of citizens generally." ${ }_{44}$ Thus, for example, Eisgruber and Sager agree that workers who quit their jobs because of religious conflicts with the work should be entitled to workers compensation, however, they argue that similar treatment should be given to workers with comparable conscientious, but secular, conflicts. ${ }^{45}$ According to Eisgruber and Sager, there is "no constitutional justification for the privileging of religion; to the contrary the idea of a broad privilege for religiously motivated conduct baldly contradicts the best understanding of the foundations of religious freedom."46 Under this standard, Eisgruber and Sager argue that the RFRA is unconstitutional because it amounts to "privileging" religion:

Equal regard calls upon courts to guard against policies that disfavor fundamental secular commitments by comparison to religious interests. The Religious Freedom Restoration Act explicitly protects only those interests which are religious. If the statute's preference to religion is interpreted restrictively and exclusively, the resulting favoritism for religion is probably unconstitutional. ${ }^{47}$

In the next section of this article, I will provide reasons for why these arguments, in either their extreme form, or the milder form of "equal regard," should not be accepted.

\section{The Inevitability of "Singling Out" Religion}

\section{A. Privilege and Balance}

At one level, it is puzzling that so many scholars and commentators would regard the "singling out" of religion as problematic under our Constitution. The very text of the Constitution "singles out" governmental acts respecting an establishment of religion or prohibiting the exercise of religion for special protections that are not accorded to any aspect of human life. Religion is uncontroversially "singled out" under the Establishment Clause. Government may subsidize or promote any number of ideas, institutions, and activities - such as Planned Parenthood, the "Got Milk?" campaign, Mexican Independence Day,

44. Eisgruber \& Sager, supra note 43, at 1285.

45. Id. at 1293.

46. Eisgruber \& Sager, RFRA, supra note 43, at 448.

47. Eisgruber \& Sager, Vulnerability, supra note 43, at 1308. 
or controversial art exhibits - however, it may not similarly subsidize or promote religion. (As noted below, this fact does not prevent the government from extending subsidies on neutral terms to religious institutions that provide public benefits.) On most matters, the government is free to join its voice to public debate, and in the process, take controversial positions. However, with regard to religion, the government must be silent, or evenhanded. If singling out religion were constitutionally problematic, this difference in treatment would be difficult to explain.

Critics of free exercise exemptions complain, for example, that a worker who is constructively discharged because of religious conflicts with work is entitled to workers compensation, but a worker with secular objectives to the work, such as environmental issues, is not entitled to such compensation. However, before declaring this discrepancy unfair, it is necessary to illustrate that the government can (and does) endorse the ideals of environmentalism, the government can (and does) inculcate environmentalist sensibilities in the public schools, the government can (and does) establish an agency to promote the objectives of environmentalism, and the government can (and does) use the coercive power of the state to promote environmentalist objectives. If we had a constitutional provision protecting the free exercise of beliefs about environmental protection, and forbidding the government to establish an orthodoxy on that subject, the environmentalist worker would be protected, and each of the above policies would also be unconstitutional. However, beliefs about environmental protection are not treated the same as beliefs about religion. With respect to religion, the government's hands are tied. In regard to other secular causes, the government is free to impose these types of burdens, but it is also free to promote the cause through legislative policy. I do not believe that those commentators who believe it is unfair to protect the religious worker, but not the environmentalist, would make the same argument if such an approach required treating environmentalism the same as religion across the board.

Similarly, Kramnick and Moore may believe that religion should receive no more protection from government regulation than General Motors. However, they do not discuss the flip side of their argument. The government is also free to promote and subsidize General Motors. (Remember the Chrysler bailout?) To treat General Motors in the same way as we treat religion would constitutionalize a radical version of laissez-faire deregulation. To treat religion in the same ways we treat General Motors would provide the government virtual carte blanch to promote, inhibit, and control religion. Neither alternative 
seems remotely similar to our constitutional tradition of religious freedom, or our basic intuitions about the proper scope of liberal government.

The only constitutional regime that would not "single out" religion would be one that deconstitutionalized the issue of religion, leaving issues regarding the extent of regulation, subsidy, and control of religious activities to the discretion of the political branches. Even if the First Amendment were interpreted, as the late Professor Philip Kurland famously suggested and some modern scholars continue to propose, as a prohibition of all laws that use the category of "religion" as a criterion for the distribution of benefits or the imposition of penalties, ${ }^{48}$ such a rule would "single out" religion by requiring the government to refrain from using religion as a basis for legal categorization.

When we look at the Religion Clauses as a whole, we see that the question of singling out religion is not one of "privilege," but rather one of balance. The Free Exercise and Establishment Clauses serve a complementary function: to reduce the power of government over religion, whether to help, hurt, or control, to the greatest extent consistent with the achievement of legitimate secular objectives. Interference with the practice of religion is avoided where possible; support for religion is virtually prohibited; and control over religion is kept to a bare minimum. This approach means that religion is free, however, it also means that religion cannot use the arm of the state to affirmatively advance its own objectives. Such an approach creates a trade-off that few other ideologies or systems of belief would care to make. Eisgruber and Sager give this hands-off principle the unattractive label of "unimpaired flourishing," 49 however, that is a misleading term. Not only must religion be "unimpaired," but it must also be unsponsored, uncontrolled, and unpromoted. As a result, religion may not "flourish," but rather, wither away. The fate of religion will be determined not by the government, but by "the zeal of its adherents and the attractiveness of its dogma." 50 The unifying principle, in brief, is "let it alone." Of course, in a complex world in which the government interacts with almost every facet of our lives, it is not always easy to determine what course of action best leaves religious matters to private judgment. However, whatever the specific context,

48. See Philip B. Kurland, Religion and the Law of Church and State and the SuPREME COURT 18 (1962); Philip B. Kurland, The Irrelevance of the Constitution: The Religion Clauses of the First Amendment and the Supreme Court, 24 VILL. L. Rev. 3, 24 (Nov. 1978). For a modern example, see Mark V. Tushnet, "Of Church and State and the Supreme Court": Kurland Revisited, 1989 Sup. CT. Rev. 373 (1989).

49. Eisgruber \& Sager, Vulnerability, supra note 43, at 1254.

50. Zorach, 343 U.S. at 313. 
religion receives special consideration, not so that it can be privileged, but rather, that it may be left alone.

\section{B. The Deliberate Character of the Special Treatment of Religion}

Religion was not "singled out" in the constitutional text by accident. The Framers of the First Amendment seriously considered enacting constitutional protection for "conscience," presumably a broader term, and deliberately adopted the term "religion" instead. ${ }^{51}$ Madison's original draft contained both a "religion" clause and a "conscience" clause. ${ }^{52}$ The Select Committee shortened Madison's proposal, eliminating the "religion" provision and protecting the "equal rights of conscience." 53 The full House of Representatives returned to Madison's idea of protecting both ideas: "Congress shall make no law establishing religion, or prohibiting the free exercise thereof, nor shall the rights of conscience be infringed." 54 The presence of both "religion" and "conscience" in different clauses of this proposal strongly suggests that the two terms were not considered synonymous. The Senate then voted on a succession of drafts, some protecting "the rights of conscience" and some protecting the "free exercise [of religion]." 55 In the end, the Framers settled on the term "religion." It is evident from this history that the Framers of the First Amendment considered the possibility of extending protection to the full range of "conscience," but determined, in the end, to protect "religion" alone. This historical fact casts doubt on the suggestion of some commentators ${ }^{56}$ that the constitutional term "religion" should be broadly interpreted in order to encompass secular claims of conscience. Regardless of whether such a broad interpretation would be a good idea, ${ }^{57}$ such a step would constitute an amendment, not an interpretation, of the First Amendment, and one that the Framers specifically considered, debated, and ultimately rejected.

51. For a more detailed discussion of the framing of the Free Exercise Clause and the relationship of "religion" to "conscience," see Michael W. McConnell, The Origins and Historical Understanding of Free Exercise of Religion, 103 HARv. L. REv. 1409, 1480-1500 (May 1990).

52. Cogan, supra note 1 , at 1.

53. Id. at 2 (Report of House Committee, July 28, 1789).

54. Id. at 3 (House Resolution, August 24, 1789).

55. Id. at 3-6 (Senate Consideration, August 25 - September 9, 1789).

56. See, e.g., Douglas Laycock, Religious Liberty as Liberty, 7 J. Contemp. Legal Issues 313, 326-39 (1996); Ira Lupu, The Trouble With Accommodation, 60 Geo. Wash. L. Rev. 743, 778-79 (Mar. 1992); Rodney K. Smith, Converting the Religious Equality Amendment into a Statute with a Little Conscience, 1996 BYU L. REv. 645, 662-75.

57. Eisgruber and Sager explain why such an expansion is normative undesirable. Eisgruber and Sager, Vulnerability, supra note 43 , at $1268-70$. 
In confirmation of this conclusion, the Framers of the Bill of Rights engaged in a focused debate on religious accommodation in connection with what is now the Second Amendment, at roughly the same time as the debates over the First Amendment. ${ }^{58}$ Madison proposed an amendment to exempt from militia service those who were "religiously scrupulous of bearing arms." 59 The proposal passed the House of Representatives and failed narrowly in the Senate. Interestingly, some members of the First Congress, as if they anticipated the modern argument, insisted that any exemption should be confined to the religious and not extended to "those who are of no religion." 60 One representative explained that "[i]t has been urged that religion is on the decline; if so, the argument is more strong in my favor, for when the time comes that religion shall be discarded, the generality of persons will have recourse to these pretexts to get excused from bearing arms." 61 No one suggested broadening the exemption to nonreligious objectors.

As already noted ${ }^{62}$ most opponents did not disagree with the underlying objective of the amendment, they objected to the proposal to constitutionalize the matter rather than leaving it to ordinary legislation. In fact, the representative who moved to strike the proposal commented that he had "no reason to believe but the legislature will always possess humanity enough to indulge this class of citizens in a matter they are so desirous of." However, he argued that if the proposal were made "part of the constitution, it will be a question before the judiciary, on every regulation you make with respect to the organization of the militia, whether it comports with this declaration or not," and that it would be "extremely injudicious to intermix matters of doubt with fundamentals." 63 This reasoning is not unlike the reasoning of Justice Scalia in the Smith case. In Smith, the Court did not dispute the "desirability" of free exercise exemptions ${ }^{64}$ but concluded that it is "not within the judicial ken" to determine how important or central a religious practice is, or to balance this against governmental interests. ${ }^{65}$ It is "horrible to contemplate," the opinion stated, a legal rule under which "courts would constantly be in the business of deter-

58. For a more detailed discussion, see Michael W. McConnell, The Origins and Historical Understanding of Free Exercise of Religion, supra note 51, at 1495-96, 1500-03.

59. Cogan, supra note 1 , at 169.

60. Id. at 189 (Rep. Scott).

61. Id. at $189-90$.

62. Id.

63. Cogan, supra note 1 , at 187 (Mr. Benson).

64. Smith, 494 U.S. at 890.

65. Id. at 887 (citation omitted). 
mining whether the 'severe impact' of various laws on religious practice ... suffices to permit us to confer an exemption."66

From the debates over the drafting of the Bill of Rights, we can see that some Framers believed that religious concerns should be given constitutional protection, some thought protection for religious concerns was desirable but should be left to legislative discretion, and some opposed exemptions altogether; however, no member of the First Congress expressed the view that it is improper to extend protection to "religious sentiments" without treating nonreligious sentiments with equal regard.

In recent years, there has been extensive debate over whether, during the founding period, religious accommodation was understood primarily as a constitutional obligation of government or as a matter of legislative discretion. ${ }^{67}$ However, not one historian or constitutional scholar has claimed that the founding generation deemed religious accommodations illegitimate. Accommodations of religion during the years leading up to the framing of the First Amendment were common (the most frequent examples were exemption from military conscription or jury duty, exemption from oath requirements, and exemption from tithes). ${ }^{68}$ These exemptions illustrate that "singling out" religion for special protection was deemed permissible, even if not constitutionally compelled.

In light of this history, it is not plausible to object to interpretations of free exercise on the basis that they do not accord "equal regard" to secular forms of conscience because the decision to differentiate between the two was made by the Framers. As Professor Douglas Laycock has observed:

Religion is unlike other human activities, or at least the founders thought so. The proper relation between religion and government

66. Id. at 889 n.5.

67. Generally supporting free exercise exemptions include Michael W. McConnell, The Origins and Historical Understanding of Free Exercise of Religion, supra, note 51; Michael W. McConnell, Freedom from Persecution or Protection of the Rights of Conscience? A Critique of Justice Scalia's Historical Arguments in City of Boerne v. Flores, 39 WM. \& M. L. REv. 819 (1998); John Witte, Jr., The Essential Rights and Liberties of Religion in the American Constitutional Experiment, 71 No'Tre Dame L. Rev. 371 (1996); Douglas Kmiec, The Original Understanding of the Free Exercise Clause and Religious Diversity, 59 UMKC L. REv. 591 (1991); W. Cole Durham, Jr., Religious Liberty and the Call of the Conscience, 42 DEPAul L. R. 71 (1992). Arguing that free exercise exemptions were not understood to be required include Michael $\mathbf{J}$. Malbin, Relicion and Politics (1978); Philip Hamburger, A Constitutional Right of Religious Exemption: An Historical Perspective, 60 Geo. Wash. L. Rev. 915 (1992); Ellis M. West, The Case Against a Right to Religion-Based Exemptions, 4 Notre Dame J. L. Ethics \& Pub. Pol'y 623 (1990); Gerard Bradley, Beguiled: Free Exercise Exemptions and the Siren Song of Liberalism, 20 Hofstra L. Rev. 245 (1991).

68. See McConnell, supra note 51, at 1466-73. 
was a subject of great debate in the founding generation, and the Constitution includes two clauses that apply to religion and do not apply to anything else. This debate and these clauses presuppose that religion is in some way a special human activity, requiring special rules applicable only to it. ${ }^{69}$

The text does not necessarily compel the conclusion that the Smith decision was wrong or that religious exercise is entitled to protection from formally neutral laws, however, it does compel the conclusion that religion has a special and unique place in our constitutional order.

Eisgruber and Sager declare the argument from constitutional text "singularly unconvincing," however, their reaction seems to be based on a general disdain for reliance on the words and history of the Constitution as a basis for interpretation. "[T]he project of constitutional interpretation," they say, "involves the pragmatic pursuit of political justice, not the positivist recovery of fixed historical meaning."70 Eisgruber and Sager concede that the textual references to religion demonstrate that "religious activities are more important than matters of fashion or recreation," however, they assert that the text "provide[s] no ground for privileging religion by comparison to comparably serious secular commitments." 71 This statement represents the entirety of their textual argument. Yet the constitutional text refers to "religion," and not to "secular commitments." No mention was made in 1789 of fashion or recreation, however, the Framers of the First Amendment considered, and rejected, drafts that would have protected "conscience." Eisgruber and Sager do not explain why this fact is not significant. They also argue that the enactment of the Equal Protection Clause "deprived religion of any special constitutional respect it had enjoyed before Reconstruction."72 Eisgruber and Sager fail to cite any evidence to support their remarkable proposition. As the heirs of the abolitionist movement, which was itself an offshoot of the Second Great Awakening, it would be surprising if the Framers of the Fourteenth Amendment intended to deprive religion of any of the constitutional respect it had received during its historical existence. The most complete historical analysis of that issue suggests that the Framers of the Fourteenth Amendment embraced, rather than rejected, the idea of free exercise exemptions for religion. ${ }^{73}$

\footnotetext{
69. Douglas Laycock, The Remnants of Free Exercise, 1990 Sup. CT. REv. 1, 16.

70. Eisgruber \& Sager, Vulnerability, supra note 43, at 1270.

71. Id. at 1271 .

72. Id. at 1272 .

73. Kurt T. Lash, The Second Adoption of the Free Exercise Clause: Religious Exemptions Under the Fourteenth Amendment, 88 Nw. U. L. Rev. 1106 (1994).
} 
In short, the text and history of the First Amendment is impossible to square with the theory that religious accommodations are necessarily unconstitutional.

\section{Ideas and Arguments}

The Religion Clauses of the First Amendment were not created out of whole cloth, but rather, were the culmination of centuries of theological and political debate over the proper relation between spiritual and temporal authorities. ${ }^{74}$ This discussion was part of a wider debate regarding the relation of government to other aspects of human society. To some extent, the religious debate was parallel to, or a model for, debate about other issues. For example, the struggle for the freedom to publish religious tracts was a precursor to the struggle for the freedom of the press more generally, as the freedom to gather together for purposes of religious worship was for the freedom of assembly. In this sense, religious freedom was not always "singled out," but was sometimes treated as the paradigm or prototype for liberal freedom more generally. ${ }^{75}$ However, a great deal of the debate was conducted in terms that were distinctive to religion, and remain inapplicable to nonreligious matters.

\section{Separation of Church and State}

One of the central (if often misunderstood) ideas in our constitutional tradition is that the institutions of church and state must be separate and independent from one another. ${ }^{76}$ The famous phrase, "the wall of separation between church and state," 77 emerged from the pen of Thomas Jefferson, however the idea was much older. The concept was rooted in a centuries old struggle between ecclesiastical and civil authorities over who would control the church, and what part, if any, the church would play in the selection and validation of political leaders. Indeed, the idea of a jurisdictional separation between religious and temporal authority has roots which extend as far back as the Fifth Century, long before there was any real conception of individual con-

74. See John Witte, Jr., Religion and the American Constitutional Experiment 7-55 (2000).

75. I develop this theme more fully in Michael W. McConnell, Why ls Religious Liberty the "First Freedom"?, 21 CARDozo L. Rev. 1243, 1251-53 (2000).

76. Elsewhere, I have pointed out the inadequacies of the idea of "separation" to account for our constitutional tradition of religious liberty. See Michael W. McConnell, Believers As Equal Cilizens, in Obligations of Citizenship and Demands of Faith 90, 93-97 (Nancy L. Rosenblum, ed., 2000).

77. Thomas Jefferson, Letter to the Danbury Baptist Association (Jan. 1, 1802), reprinted in 5 The Founders Constitution 96 (Philip Kurland \& Ralph Lerner, eds., 1987). 
science in matters of religion in papal teachings regarding the freedom of the church from the control of the Emperor. ${ }^{78}$ This separation is deeply imprinted in the Western historical experience, with such episodes as the martyrdoms of Becket and More to impart the lesson to succeeding generations. Church-state separation was most immediately an extension of Protestant "two kingdoms" theology, which was preached in different forms by the great Reformers, Luther and Calvin, and deeply affected the political theory of Western Europe. ${ }^{79}$ Two-kingdoms theology conceived of humans as owing allegiance to two different sets of authorities, the spiritual and the temporal. "God has appointed two kinds of government in the world," explained Isaac Backus, a Baptist leader and one of the most influential advocates of religious freedom at the Founding. These governments "are distinct in their nature, and ought never to be confounded together; one of which is called civil, the other ecclesiastical government." made this separation between spiritual and temporal spheres the centerpiece of his prescription for religious toleration, which in turn was a principal influence on Jefferson. ${ }^{81}$ For the protection of religious liberty, Locke "esteem[ed] it above all things necessary to distinguish exactly the business of civil government from that of religion and to settle the just bounds that lie between the one and the other." 82 The "whole jurisdiction" of government, he wrote, is confined to "civil concernments," which consisted of protecting the "life, liberty, health, and indolency of body; and the possession of outward things, such as money, lands, houses, furniture, and the like," leaving the "salvation of souls" to religious authorities. ${ }^{83}$

It is difficult to say whether this duality between "church" and "state" reflects an essential ontological difference, arising from the nature of the subject, or whether it is a product of the post-pagan West-

78. See Brian Tierney, Religious Rights: A Historical Perspective, in Religious LiberTy in Western Thought 29, 34 (Noel Reynolds \& Cole Durhan, eds., 1996).

79. See 2 John Calvin, Institutes of the Christian Religion 184 (Ford L. Battle ed. \& trans., 1975); Martin Luther, Temporal Authority: To What Extent It Should Be Obeyed, in 45 LUTHER's Works 75, 81-129 (Walther I. Brandt ed. \& J.J. Schindel trans., 1962); see generally Arlin M. Adams \& Charles J. Emmerich, A Nation Dedicated to Religious Liberty 3 , 56-57 (1990).

80. Isaac Backus, An Appeal to the Public for Religious Liberty (1773), reprinted in PolrTical Sermons of the American Founding Era 334-35 (Ellis Sandoz ed., 1991) [hereinafter PoltriCAL SERMONS].

81. See Kessler, Locke's Influence on Jefferson's "Bill for Establishing Religious Freedom," 25 J. Church \& State 231 (1983).

82. John Locke, Essay on Toleration, in 6 THE WORKs OF JOHN LOCKE 1, 9 (Locke 1823 and photo. reprint 1963).

83. Id. at 10 . 
ern historical experience. ${ }^{84}$ The idea may even be specific to the Biblical religions, with their conception of a loving and all powerful God who is the source of moral value, and thus, in competition with earthy rulers. It is not obvious that other religions present the same dualistic relationship to the state. I personally incline toward the essentialist explanation, believing that matters of the spirit are fundamentally outside the sphere of force and coercion, which is the province of the state. With what other human activity, commitment, worldview, or institution is the government so fundamentally separated? Surely, not all matters of "conscience," for who would argue that state action should be unaffected by convictions of right and wrong, or that the state is disabled from attempting to convey ideas of right and wrong to succeeding generations? Nonetheless, whether this dualism is natural and essential, or historical and socially constructed, is essentially irrelevant because it is so deeply engrained in our political, constitutional, and theological traditions that it must be accepted as an assumption upon which our constitutional culture rests. ${ }^{85}$

One could argue that the "separation between church and state" is simply an instantiation of the more general idea of separation between public and private, which is central to liberalism. ${ }^{86}$ Viewed in this light, religion is not "singled out," but rather, is properly understood as only one example of the "private" that is protected from government interference and control. In a general sense, I believe this idea is correct. There are strong similarities between church-state doctrine and other doctrines of constitutional privacy. ${ }^{87}$ Nonetheless, rec-

84. In some cultures, such as ancient Rome, church and state were so closely tied that no useful distinction could be made between them. I am not sure whether this counts as evidence that the church-state dualism is merely conventional, or simply as evidence that there are multiple responses to the problem posed by the church-state dualism, including the answer that the dualism should be dissolved.

85. I should emphasize to the incautious reader that I am not here arguing that the idea of free exercise exemptions, or any other specific constitutional doctrine, is logically entailed by this tradition of church-state dualism, but only that thinking about religious freedom and constitutional liberty must proceed from the assumption of a dualism between religious and temporal authority.

86. See, e.g., Louis Michael Seidman, Public Principle and Private Choice: the Uneasy Case for a Boundary Maintenance Theory of Constitutional Law, 96 YALE L. J. 1006 (1987). This seems to be a major part of Eisgruber and Sager's analysis (Vulnerability, supra note 43, at 1273-74).

87. I drew parallels between church-state doctrine and the abortion question in Michael W. McConnell, The Selective Funding Problem: Abortions and Religious Schools, 104 HArv. L. REv. 989, 994-96 (1991), and between church-state doctrine and issues of sexual orientation in Michael W. McConnell, What Would It Mean To Have a "First Amendment" For Sexual Orientation?, in Sexual Orientation \& Human Rights in American Religious Discourse (Saul M. Olyan \& Martha Nussbaum, eds., 1998). 
ognition of the similarity does not eliminate the need for a "special" treatment of religion.

First, the aspects of human life that are deemed sufficiently "private" to be shielded from state power are few, and the treatment they receive from the law is correspondingly "special." 88 Thus, recognition that religious life is a subset of constitutionally protected private life does not require that religion ceases to be "singled out," but only that a few other aspects of life, such as those pertaining to procreation and childrearing, also be "singled out." Many of the secular activities whose differential treatment from religion concerns the critics of "singling out," such as the atheist-owned art museum (Justice Stevens), General Motors (Kramnick and Moore), or the secular conscientious objector to work on military projects (Eisgruber and Sager), are not "private" in any constitutionally recognized sense of that term.

Second, even among the class of human concerns deemed constitutionally "private," the applicable legal principles are not the same. The right to abortion, for example, is treated constitutionally as "private" for purposes of regulatory authority, however, when the question becomes if abortion is sufficiently "public" to warrant public subsidy, the legislature is permitted to decide. ${ }^{89}$ Families are treated as intimate associations within the protection of constitutional privacy, ${ }^{90}$ however, issues such as marriage, divorce, adoption, the education of children, and the consequences of dissolution are subject to longstanding and often quite intrusive state regulation. It is possible to draw useful comparisons between family autonomy and church autonomy, ${ }^{11}$ but there are "special" considerations applicable to each, which lead to somewhat different legal arrangements. Indeed, every human concern subsumed in the category of "the private" has its own "special" features, and none of the concerns can be treated precisely the same as any other. The attempt to ground protection for religious freedom in the wider category of freedom for intrinsically "private" matters thus falls short.

This idea may be illustrated by an example analyzed by Eisgruber and Sager. Under current constitutional doctrine, even after Smith, churches and synagogues have an absolute right to select their spiri-

88. For a summary of the modern constitutional doctrine of privacy, see Tom Gerety, Right of Privacy (Update), in EnCyClopedia of THe American Constitution, Supp. I, at 461 (Leonard Levy ed., 1999).

89. See McConnell, supra note 87.

90. Roberts v. United States JayCees, 468 U.S. 609, 619-20 (1984); see generally Robert Burt, The Constitution of the Family, 1979 Sup. CT. REv. 329.

91. See, e.g., Carl Schneider \& Margaret Brinig, An Invitation to Family Law 253 (1996). 
tual leaders without being subject to second-guessing on behalf of the state, even when the conduct would otherwise violate the anti-discrimination laws. ${ }^{92}$ This is a right that other institutions in our society do not enjoy. Businesses are subject to anti-discrimination laws, as are labor unions, political parties, newspapers, private voluntary associations, and other constitutionally protected groups. Some groups may be able to show that anti-discrimination laws are unconstitutional as applied to their particular circumstance, typically because discrimination forms a part of their expressive identity. The Ku Klux Klan, for example, could not be forced to hire black leaders, ${ }^{93}$ the Boy Scouts do not have to accept openly gay scoutmasters, ${ }^{94}$ and a theatrical director is presumably permitted to take race into account in choosing actors to play particular roles. However, the religious exemption is far broader than these examples. A church or synagogue does not need to demonstrate that employment of any particular person would be inconsistent with its expressive purpose; the law respects the fundamental autonomy of religion with respect to all employment in a religious capacity. Although this privilege is of "special character," it is well established in the caselaw, and - as Eisgruber and Sager point out - reflects a "widely held" view. ${ }^{95}$ Most people would find it shocking for the government to tell the Catholic Church or an Orthodox synagogue that it must hire women as priests or rabbis. This exemption is a fundamental aspect of the separation between church and state.

Eisgruber and Sager attempt to justify this exemption with an analogy to other distinctively private decisions. ${ }^{96}$ "Religious leaders," they say,

[a]re moral advisors, confidants, friends, and spiritual guides. The state cannot prescribe a nondiscriminatory protocol for a group's choice of the person who is to bear this private responsibility to its members any more than the state could prescribe such a protocol for the selection of a psychiatrist, or of a neighbor in whom to confide one's hopes and concerns. The aspects of religious practice that are uncontroversially secure from the reach of some state com-

92. See, e.g., Gellington v. Christian Methodist Episcopal Church, Inc., No. 99-10603, 2000 WL 192100, at *6 (11th Cir. Feb. 17, 2000); Combs v. Central Texas Annual Conference of the United Methodist Church, 173 F.3d 343, 350 (5th Cir. 1999); EEOC v. Catholic Univ. of Am., 83 F.3d 455. 470 (D.C. Cir. 1996); Young v. Northern Ill. Conference of United Methodist Church, 21 F.3d 184, 187-88 (7th Cir. 1994); Scharon v. St. Luke's Episcopal Presbyterian Hosps., 929 F.2d 360, 363 (8th Cir. 1991); Rayburn v. General Conference of Seventh-day Adventists, 772 F.2d 1164. 1168-69 (4th Cir. 1985); McClure v. Salvation Army, 460 F.2d 553, 560 (5th Cir. 1972).

93. Invisible Empire of the Knights of the KKK v. Mayor of Thurmont, 700 F. Supp. 281, 289 (D. Md. 1988).

94. Boy Scouts of America v. Dale, 120 S. Ct. 2446 (2000).

95. Eisgruber \& Sager, Vulnerability, supra note 43, at 1275.

96. Id. at 1276 . 
mands are so secure because they are private in general and recognizable ways, not because they are religious .... The controversial aspect of religious exemptions begins at precisely the point where the general shield of private behavior leaves off. ${ }^{97}$

Nonetheless, there is no general exemption from antidiscrimination laws for "private" activities. Individuals may choose their own neighbor or psychiatrist in whom to confide, however, that is only because the employment laws do not apply in such situations. If a clinic, the institutional analogue to a church in this example, discriminated in its hiring of a staff psychiatrist, no "privacy" rationale would screen the decision from the law. Employment relations, even within the private sphere, are covered by antidiscrimination laws, and enjoy constitutional protection only in narrow circumstances. In fact, contrary to Eisgruber and Sager, there is no general category of "private" employment into which clerical hiring fits. The religious exception is sui generis. If Eisgruber and Sager are correct, that the "controversial aspect of religious exemptions begins at precisely the point where the general shield of private behavior leaves off," then the exemption for clerical employment should in fact be controversial. ${ }^{98}$

Eisgruber and Sager are thus correct in stating that the separation between church and state bears a family resemblance to more general doctrines grounded in the public-private distinction; however, they are incorrect in stating that the limits of chuch-state separation are congruent with the public-private distinctions as interpreted in other areas.

A version of the public-private dichotomy that is currently the subject of renewed scholarly attention is the idea of "civil society" - the network of voluntary associations, mediating between individuals and the state, that shape and develop public values and culture. ${ }^{99}$ "Civil society" is especially important to liberal democratic regimes because the nonsectarian nature of the regimes makes them incapable of developing and inculcating public virtue. This important task is left to

97. Id. at 1276

98. It is controversial in some circles, but not for reasons relating to the "singling out" of religion. See Jane Rutherford, Equality as the Primary Constitutional Value: The Case for Applying Employment Discrimination Laws to Religion, 81 Cornell L. Rev. 1049 (1996).

99. See Peter L. Berger \& Richard John Neuhaus, To Empower People: From State to Civil Society (2d ed. 1996); Ernest Gellner, Conditions of Liberty: Civil Society and its Rivals (1994); Jean L. Cohen \& Andrew Arato, Civil Society ani Political THEORY (1992); Symposium on Legal and Constitutional Implications of the Calls to Revive Civil Society, 75 Chi.-Kent L. Rev. 289 (2000). 
institutions independent of the government. ${ }^{100}$ Churches are certainly part perhaps the paradigm of this "civil society."

One could argue that constitutional protection is given to churches because they are institutions of "civil society" not because of any considerations peculiar to religion. Such an argument, however, would be required to abstract substantially from the reality of the law. Although a wide variety of constitutional doctrines protect the autonomy of various types of civil association in various contexts, the sum of the parts is not impressive. As Professor Mark Tushnet recently concluded, "contemporary constitutional doctrine gives "civil society" a relatively small protected domain." 101 Moreover, there are few constraints parallel to the Establishment Clause that are applicable to secular civil associations. The government can require dissidents to join or contribute to labor unions and bar associations even when they disagree strongly about the ideological stances of those organizations; ${ }^{102}$ the government can give grants to support the expressive activity of private groups; and public school curriculum can inculcate controversial ideological viewpoints, as long as they are secular and not religious. Thus, while religious institutions are only but one type of "civil society" institution, they are accorded far more constitutional freedom, and entitled to far less government assistance, than any other institution.

The special character of religion within the ranks of "civil society" institutions is based, in large part, on Western historical experience. The Framers of the Constitution were well aware of three facts. First, churches had long been the primary institutions for the development and inculcation of ideas about virtue. Second, official state alignment with a single religion was very frequently a source of discord, persecution, and even civil war. Third, government support for religion tended to weaken rather than strengthen the recipient. ${ }^{103}$ In light of the third fact, the Framers realized that the advantages of the first (inculcation of public virtue) could be achieved, and the dangers of the second (discord and persecution) eliminated, by the same policy:

100. See Michael W. McConnell, The New Establishmentarianism, 75 CHI.-KeNT L. Rev. 453, 453-59 (2000).

101. Mark V. Tushnet, The Constiution of Civil Society, 75 CHI.-KENT L. REv. 379, 412 (2000) (emphasis omitted).

102. Keller v. State Bar of California, 496 U.S. 1 (1990); Abood v. Detroit Board of Education, 431 U.S. 209 (1976). On the differences between restrictions on compelled support for advocacy under the Free Speech Clause and the Religion Clauses, see Michael W. McConnell, Political and Religious Disestablishment, 1986 BYU L. REV. 405.

103. For an elaboration of these three points, see McConnell, First Freedom, supra note 75, at 1253-55. 
the disestablishment of religion. Again, it is difficult to say whether this concatenation of results was due to essential ontological differences between the religious and the secular, or is contingent on the Western historical experience. Nevertheless, it does not matter whether the differences are essential or contingent, because historical experience provides a rational justification for constitutional arrangements. It is not obvious that other features of our constitutional tradition could survive the acid bath of skeptical inquiry into whether they are based on essential features of human existence. It is enough that the American people, on the basis of the experience of their ancestors, made the determination that these restrictions and protections would be conducive to the peace and happiness of the republic, and continue to support these arrangements.

As a believer in the importance of an independent "civil society," I find the current weak state of constitutional protection for freedom of association disturbing, and believe that we should consider using the Free Exercise and Establishment Clauses as a model for heightening the protections for other civil associations. The recent decision in Boy Scouts of America v. Dale, ${ }^{104}$ protecting the right of expressive associations to control their own membership and leadership criteria, is a move in that direction. It is interesting, and encouraging, that the right to forego formal schooling for one's children, recognized in Wisconsin v. Yoder ${ }^{105}$ as applying only to religious families, has now been extended, as a practical matter, to all families under the rubric of homeschooling. Nevertheless, it is impossible to claim that religious and secular institutions within "civil society" are now treated the same way, or even that the various nonreligious civil associations are treated the same way. Moreover, as a normative matter, it is unlikely that such institutions will ever be treated the same. The concept of "civil society" is too diverse to eliminate the need for special provisions for religious associations. Religious institutions are the clearest and most firmly established examples of "civil society" institutions. While the principles of separation can be borrowed as a model for others in many cases, it would be a grave mistake to insist that the level of protection be reduced to the least common denominator.

\section{The Government is Not a Competent Judge of Religious Truth}

A second, recurring argument for free exercise and disestablishment protections was, in Madison's words, that "the Civil Magistrate

104. 120 S. Ct. 2446 (2000).

105. 405 U.S. 205 (1981). 
is [not] a competent Judge of Religious Truth."106 This statement implies an epistemic, as opposed to an institutional, basis for the special place of religion under liberal democracy. This idea remains a widely shared intuition. "Faith" is distinguished from "reason,"107 and "reason" is said to be the hallmark of liberal governance. ${ }^{108}$ Even Eisgruber and Sager acknowledge that an epistemic difference provides warrant for some degree of special treatment of religion:

[F]or purposes of assessing the impact of a sincerely held scheme of religious belief upon the believer, the ultimate truth or the reasonability of the scheme is beyond the constitutional competence of the state. This is implicit in the requirement of equal regard that the state defer to the perspective of a religious believer as to the existence of an interest of great weight within her life; it is a function of the epistemically distinct, closed logic of religious belief. ${ }^{109}$

Why is the civil magistrate an incompetent judge of religious truth? Democratic government has the greatest competency with respect to determinations about what will best serve the public interest. One could even argue that properly constituted representative institutions are a more reliable judge than any individual of the content of social ethics. Since we are each highly (and often unconsciously) self-centered, representatives of society as a whole may be more likely to develop and enforce mutually beneficial rules regarding how we should behave toward one another than any other decision making method that comes to mind. The result may not be correct, however, there is reason to believe that the result is likely to be superior to the alternatives, including one's own opinion. A great deal of what government does can be understood in these terms. Moreover, where a decision involves specialized information that is in the hands of governmental elites, a reasonable citizen is justified in treating the civil magistrate as a more competent judge than he would be himself.

This statement is not true for religious matters. The government cannot be a competent judge of religious truth because there is no reason to believe that religious understanding has been vouchsafed to the majority, or to any governmental elite. If I find that fifty-five percent of Americans believe that Elvis Presley is a god, this provides no

106. James Madison, Memorial and Remonstrance Against Religious Assessments, II 5, reprinted in KurLand \& LERnER, supra note 77 , at 83.

107. See Stephen L. Carter, Evolutionism, Creationism, and Treating Religion as a Hobby, 1987 Duke L.J. 977, 987-94; Allan Ides, Bowers v. Hardwick: The Enigmatic Fifth Vote and The Reasonableness of Moral Certitude, 49 WASH. \& LEE L. Rev. 93, 105-06 (1992).

108. On the central role of "public reason" in liberal government, see JoHn Rawls, POLITICal. Liberalism 216-20 (1993); Ronald Dworkin, Liberalism, in Public and Private MoralITY 13-43 (Stuart Hampshire ed.,1978).

109. Eisgruber \& Sager, Vulnerability, supra note 43, at 1292. 
reason for me to accept the idea. God does not speak through political majorities. As Madison illustrated, in matters of religion, on which the eternal salvation of one's soul may rest, "the opinions of men, depending only on the evidence contemplated by their own minds, cannot follow the dictates of other men." 110

Of course, religious truth is far from unique in this respect. There are many fields of knowledge where neither democratic majorities nor governmental elites have any special access to the truth. A physicist, for example, would not be moved to alter his understanding of the workings of physical laws upon learning that Congress or an administrative agency had reached a contrary conclusion. The scientist would simply run the experiment again, and check the data. There are, indeed, many matters where "the dictates of other men" are not probative about the truth of the matter. Religion is scarcely unique in this respect.

Nevertheless, merely because the civil magistrate is not a competent judge of a particular category of truth does not mean that it enjoys any special constitutional status, beyond the free speech rights enjoyed by all. For example, the fact that democratic majorities are not competent to judge the truths of physics has not been taken to imply that government should refrain from involvement with the subject. The state teaches the truths of physics in its schools, bases decisions on its understanding of physics, and doles out money to physics experiments and projects based on its evaluation of their relative merits. Heterodox views on physics warrant protection as a matter of academic freedom, however, those protections are of a different sort than the Religion Clauses provide for religion. It does not make sense to require the government to treat physics with the same scrupulous neutrality that it extends to religion. ${ }^{111}$

Another example can be found in public support for the arts. As with physics and religion, there is no reason to suppose that the civil magistrate is a competent judge of artistic merit. Art, like religion, is a deeply controversial matter. Some people object strenuously to being forced to support some artistic displays. To artists, the activity is a deeply important aspect of personal identity. It is partly for this reason that artists, like preachers, and unlike engineers, are among the

110. James Madison, Memorial and Remonstrance Against Religious Assessments $§ 1$ (1785), reprinted in KURLAND \& LERNER, supra note 77, at 82.

111. The Equal Employment Opportunity Commission recently opined that a heterodox position on a scientific matter - namely, belief in cold fusion - constitutes a religious belief and is thus protected against discrimination. See Curt Supplee, EEOC Backs "Cold Fusion" Devotee, Aug. 23, 2000, W Ash. Post at A23. An assertion that will strike most people as absurd. 
most assertive of groups about the importance of being given unfettered freedom of expression. Nevertheless, the legal regimes applicable to art and religion are entirely different. There are courses in art in every public school, and no one worries that they may problematically shape the artistic sensibilities of the younger generation. There is a National Endowment for the Arts (NEA), which distributes funds on the basis of the professional judgment of government appointed experts about relative artistic quality. Such a system surely has an effect on the types of art that are produced. In contrast, public schools do not offer courses that train children how to engage in or appreciate religion. In addition, there are no boards of government appointed religious experts empowered to decide which preachers should receive public subvention. We respect the rights of dissenters not to be forced to contribute to the dissemination of religious messages, and realize that government power to determine the most worthy recipients of public largesse would be a threat to the freedom of religion. None of these ideas are true of art.

It may be tempting to attribute the special character of religion, in this respect, to an epistemic difference between "faith" and "reason." Such arguments should be advanced with caution. "Faith" and "reason" are not opposite, or even dichotomous, but rather, are overlapping terms. Faith is a warranted confidence in matters that cannot be proven with certitude. The fact that sources of religious revelation differ from tradition to tradition, and person to person, makes it dangerous to generalize, however, it is safe to state that in the predominant religious tradition of the West, faith and reason are more complementary than opposed. In arriving at a faith position, believers employ all the standard tools of reason. Professor Larry Alexander argues that a person's religious beliefs are "supported in exactly the same way as are her beliefs that Washington was the first president, that Kinshasha is the capital of Zaire, that Maris hit sixty-one home runs, and that the speed of light is constant." 112 Alexander explains that a person "does not believe any of these things based on first-hand observation, and the last item she finds counter-intuitive and impossible to conceptualize, though she believes it, nonetheless." 113 Under the same analysis, individuals and governments make judgments about many matters that are no less controversial than religion and no more susceptible to objective reason. Among these are questions of esthetics, loyalty, sentiment, and many aspects of morality. Indeed, some modern theories

112. Larry Alexander, Liberalism, Religion, and the Unity of Epistemology, 30 SAN DIEGo L. REv. 763, 769 (1993).

113. Id. 
of the philosophy of knowledge suggest that even seemingly objective forms of knowledge, like science, rest ultimately on the same type of faith claims that undergird religious beliefs. ${ }^{114}$

This article is not the place, nor am I the person, to resolve these epistemological debates. My own inclination is to reject the claim that the apprehension of religion truth rests on the "same" epistemic foundation as these other judgments of esthetics, ethics, science, or anything else. However, I would also reject the claim that there is any common epistemic method ("reason") that undergirds each of these fields. We judge different matters by different standards of evidence and by different faculties of the human mind, and we cannot expect agreement as to what those standard are, or how to employ the different faculties. Religious judgments are thus different, but they are not in a class by themselves.

There is, however, a widespread consensus in our society, shared equally by believers and unbelievers, about one idea: religion, like love, is a judgment most of us prefer to make for ourselves. This statement is especially true in our individualist culture, so heavily influenced by Protestantism, which treats every person as equally capable of receiving the revelation of God's will. The incompetence of the magistrate to judge religious truth, coupled with this individualist premise, has produced a constitutional bargain in which the government is restrained from establishing any form of religious orthodoxy. That fact "singles out" religion, or sets it apart from government in a way that no other worldview is set apart. However, religion is manifestly not a "privilege" that benefits believers at the expense of everyone else. Atheists, agnostics, and other skeptics, no less than believers, benefit from the constitutional principle stripping the civil magistrate of power to enforce religious orthodoxy.

Consider the issue of school prayer. Unless religion is somehow constitutionally special, it would be difficult to justify the ban on voluntary school prayer. In school, children are required to recite many things, from Shakespearean sonnets to the elements in the periodic table. If atheists are correct, then prayers are nothing but nonsense, such as like Lewis Carroll's Jaberwocky. What is the injury in being asked to spout nonsense words? One might respond that religion, unlike nonsense, is controversial and that the government is wrong in attempting to impose any particular view. However, religion is not

114. See, e.g., Frederick Gedicks, Public Life and Hostility to Religions, 78 VA. L. REv. 671 (1992); David Caudill, A Calvinist Perspective on the Place of Faith in Legal Scholarship, in Christian Perspectives on Legal Thought (Angella Carmella, et al. eds, forthcoming 2001). 
the only subject where schoolchildren are entitled to draw their own conclusions, or likely to be sensitive to governmental pressure. In West Virginia Board of Education v. Barnette, ${ }^{115}$ the Court held that it is unconstitutional for public schools to punish students for refusing to participate in the flag salute. The majority opinion contained the following broad declaration:

If there is any fixed star in our constitutional constellation, it is that no official, high or petty, can prescribe what shall be orthodox in politics, nationalism, religion, or other matters of opinion or force citizens to confess by word or act their faith therein. If there are any circumstances which permit an exception, they do not now occur to us. ${ }^{116}$

As this language suggests, we have a general constitutional principle against the imposition of orthodoxy with respect to politics, nationalism, and other matters of opinion, as well as religion. School prayer fits neatly within this broader category. However, note that the holding in Barnette went no further than to forbid the punishment of schoolchildren for not participating in the flag salute. The Court did not prevent the government from encouraging participation in the flag salute, and provided no protection against peer pressure or other subtle pressure to conform. On many subjects, such as smoking, abstinence, and deciding whether capitalism is a good system, government schools "prescribe what shall be orthodox" by methods (usually) short of actual coercion. Imagining a school which did not subscribe to such a system is impossible. In the School Prayer Cases, ${ }^{117}$ by contrast, government schools were forbidden from composing or conducting prayers, although the plaintiffs were not threatened with punishment for failing to join in on the prayers. That is a very different conclusion, arising from our constitutional tradition that the imposition of a religious orthodoxy is a more serious affront to liberal values than the imposition of orthodoxy on other subjects. This concept is a difference that unbelievers, as well as believers who wish to control the religious upbringing of their children, presumably celebrate.

\section{Religious Freedom as an Inalienable Right and Duty to God}

The final, and perhaps the most important, argument for the freedom of religion during the formative period was that religious freedom was not merely a matter of personal autonomy, but rather, arose

115. 319 U.S. 624 (1943).

116. Id. at 642 .

117. School District of Abington Township v. Schempp, 374 U.S. 203 (1963); Engel v. Vitale, 370 U.S. 421 (1962). 
from the duty of each person to worship God in accordance with the dictates of conscience. In the key paragraph of his Memorial and Remonstrance Against Religious Assessments, James Madison reasoned as follows:

The Religion then of every man must be left to the conviction and conscience of every man; and it is the right of every man to exercise it as these may dictate. This right is in its nature an unalienable right. It is unalienable, because the opinions of men, depending only on the evidence contemplated by their own minds cannot follow the dictates of other men: It is unalienable also, because what is here a right towards men, is a duty towards the Creator. It is the duty of every man to render to the Creator such homage and such only as he believes to be acceptable to him. ${ }^{118}$

In this argument, Madison drew on several hundred years of dissenting Protestant thought, in which the argument for religious freedom was developed. ${ }^{119}$ William Penn, for example, had written in The Great Case of Liberty of Conscience:

[W] hosoever shall interpose their authority to enact faith and worship in a way that seems not to us congruous with what he has discovered to us to be faith and worship (whose alone properly it is to do it) or to restrain us from what we are persuaded is our indispensable duty, they evidently usurp this authority, and invade [God's] incommunicable right of government over conscience . . . ${ }^{120}$

This argument was central to the eventual triumph of disestablishment and free exercise because it showed that attempts to use government power to foster religious truth were doomed to failure, and even worse, were an attempt to usurp the place of God, who was Lord of the conscience.

Freedom of religion was thus not a claim of personal autonomy, but rather an allocation of authority between two jurisdictions: the earthly and the divine. Attempts to coerce religion were an invasion of God's prerogative. Elisha Williams, a New Light Congregationalist and Rector of Yale, drew an analogy to one king attempting to govern the people of another kingdom:

[I]f Christ be the Lord of the conscience, the sole King in his own kingdom; then it will follow, that all such as in any manner or degree assume the power of directing and governing the consciences of men, are justly chargeable with invading his rightful dominion; He alone having the right they claim. Should the king of France

118. James Madison, Memorial and Remonstrance Against Religious Assessments $\$ 1$ (1785), reprinted in KURLAND \& LERNER, supra note 77, at 82.

119. See generally McConnell, First Freedom, supra note 75 at 1245-57.

120. William Penn, The Great Case of Liberty of Conscience, in 2 THE WORKS OF WILLIAM PENN 135 (London 1726). 
take it into his head to prescribe laws to the subjects of the king of Great Britain; who would not say, it was an invasion of and insult offer'd to the British legislature. ${ }^{121}$

If believed, this argument explicitly distinguishes religious freedom from other liberties of the individual, and explains why religion is "singled out" for special insulation from governmental influence or control. No other freedom is a duty to a higher authority. Nevertheless, can this account of religious freedom be accepted today?

This rationale can most easily be accepted by those who accept the idea of a divine authority whose demands are, as Madison stated, "precedent both in order of time and degree of obligation, to the claims of Civil Society."122 This idea may be sufficient in a nation, such as the United States, where the vast majority of the people believe in the existence of a God. However, belief in the reality of a God is not necessary to the argument. An individual needs only to believe conditionally that if there is a God, this idea can be revealed only through the "conviction and conscience" of the individual and not through the hand of the state. Most atheists and agnostics share that opinion. Indeed, sincere atheists and agnostics are often passionate in the conviction that the force of the state should not be brought to bear in support of any understanding of religious truth. Moreover, it is logically possible, indeed humane and praiseworthy, for those who do not believe in the existence of God, but who recognize that many of their fellow citizens do, to refrain from using the power of the state to create conflicts with what are perceived (even if incorrectly) as divine commands.

We might draw an analogy to citizens of other nations, or to children of other parents. When a citizen of another nation is in our midst, we go out of our way to avoid putting him into a position of conflict between our ways and loyalty to his own country, not because we agree with his assessment of the virtues of his own land, but rather, because we recognize the virtue of patriotism even in a person whose patria we do not admire. Similarly, if the children of other parents are in our home, we attempt to avoid situations in which the teachings of their parents are challenged by the practices of our home. We do not show movies their parents would disapprove of (even if we disagree), or serve foods they would not be permitted to eat at home (even if we think the restrictions are pointless). We give respect to the obligations

121. Elisha Williams, The Essential Rights and Liberties of Protestants (1744), reprinted in Political Sermons of the American Founding Era 51, 65.66 (Ellis Sandoz ed., 1991).

122. James Madison, Memorial and Remonstrance Against Religious Assessments $§ 1$ (1785), reprinted in KURLAND \& LERNER, supra note 77 , at 82 . 
of others to carry out duties to the authorities in their lives, even when we ourselves do not recognize or agree with those authorities. On this ground, even those who do not recognize the existence or authority of a God may well believe that the nation should guarantee the free exercise of religion.

\section{Religion and "Nonreligion"}

Much of the confusion on this subject comes from an ambiguity about what it means to "single out" religion. A common misconception is that "religion" is in one category, and everything else, typically called "nonreligion," is in another category. This conception has been fueled by the Supreme Court's ill considered, but much quoted, statement in Everson v. Board of Education that the government must be "neutral between religion and nonreligion." 123 In fact, there is no identifiable entity that goes by the name of "nonreligion." Rather, there are an infinite number of ideas, highly disparate among themselves, that are not religious. A better conception of "singling out" is that religion is one of many things that are "singled out" for special constitutional treatment. Speech, for example, is "singled out" because claims of harm to others as a result of speech are treated with far greater skepticism than claims of harm from other activity. "Sticks and stones may break my bones but words will never hurt me." As a philosophical or ontological proposition, this is not true: words can wound. However, for a combination of historical, experiential, and prudential reasons, we treat speech as if it were special, and tolerate harms from speech that we would not tolerate from other sources.

The Constitution "singles out" a number of ideas, interests, and concerns. Among them are property, self-incriminating statements, punishment, liberty, habeas corpus, ex post facto laws, involuntary servitude, voting rights, and rights deemed "fundamental." Each of these examples receives special treatment, though not the same type of special treatment. The special treatment of each of these matters can be subjected to skeptical analysis, and a critic can no doubt identify cases in which it seems arbitrary to accord constitutional protection to an activity falling within the definition and deny it to a close analog. (Why should cable television companies have a constitutional defense against "open access" regulations when natural gas companies do not?124 Why should teenagers be able to get an abortion without parental permission when they could not get a heart operation? ${ }^{125}$ )

123. 330 U.S. 1,18 (1947).

124. See Turner Broad. Sys., Inc. v. FCC, 512 U.S. 644 (1994).

125. See Bellotti v. Baird, 443 U.S. 622 (1979). 
Nevertheless, each of these concepts receives special treatment by the Constitution, and in each case such treatment can be defended by a combination of philosophical arguments, experiences, prudential judgments, and popular intuitions.

This is the sense in which religion is "singled out." Not in contradistinction to "nonreligion," but rather, as one of a great many human concerns that are insulated, for a variety of reasons and in a variety of ways, from the play of democratic politics.

\section{The Incoherence of the Theory of "Equal Regard"}

As already noted, ${ }^{126}$ Professors Eisgruber and Sager have proposed a theory that justifies substantial protection for religious freedom while condemning the special place of religion in our constitutional tradition. They entitle this theory the principle of "equal regard," which "requires simply that government treat the deep, religiously inspired concerns of minority religious believers with the same regard as that enjoyed by the deep concerns of citizens generally."127 Eisgruber and Sager not only claim that this approach is more consistent with First Amendment values, but that it will also provide a stronger basis for principled decision making, in contrast to the traditional "compelling interest" doctrine, which "offers neither conceptual nor practical guidance for making the compromises necessary to reach an appropriate degree of accommodation for religious interests." 128 "Equal regard," they say, is "normatively attractive, conceptually precise, and describes a liveable world: a world that accommodates the deep, religiously inspired concerns of minority religious believers to the same degree as the deep concerns of citizens generally." 129

In the end, the theory of "equal regard" does not live up to this billing. Far from being "conceptually precise" and "liveable," the theory of "equal regard" is deeply incoherent and ultimately meaningless. According to the "equal regard" approach, a court in a free exercise case should ask how other "deep interests" are treated (either in reality or as a hypothetical matter), and should insist that religious interests be treated as well, and no better. However, the answer to this question depends entirely on the choice of a comparison group. If the religious claim is compared to the strongest and most powerful secular analog, then the "equal regard" test is virtually indistinguishable from the compelling interest test. Only the most compelling of

126. Eisgruber and Sager, Vulnerability, supra note 43.

127. $l d$. at 1285 .

128. Id. at 1301.

129. Id. 
governmental interests are protected absolutely, with no exceptions. However, if the religious claim is compared to weak secular analogs, it will relegate religious interests to second-class status. There is nothing in "equal regard" theory that guides the choice of comparisons, and in principle, such a guide cannot exist.

Eisgruber and Sager explain their approach by reference to hypotheticals based on Thomas $v$. Review Board, ${ }^{130}$ in which a Jehovah's Witness, named Thomas, was held constitutionally entitled to unemployment compensation after he was discharged for refusal to work on armaments. Under their theory, the court is obliged to "defer to the perspective of a religious believer" regarding the importance of his belief, and is obliged to treat that belief no less favorably than other claims that are held in highest regard. "The protection of religious conscience requires that the state treat religious belief as a "black box"; for purposes of assessing the impact of a sincerely held scheme of religious belief upon the believer, the ultimate truth or the reasonability of the scheme is beyond the constitutional competence of the state."131 This idea can be entitled Equal Regard Principle Number One: sincere religious claims must be assumed to be of great importance.

Now comes the second stage in the analysis, in which Eisgruber and Sager posit the existence of a "Secular Thomas," 132 identical to the real Thomas except that his motivations for pacifism are nonreligious. Eisgruber and Sager maintain, contrary to current law, that "Secular Thomas" should also receive unemployment compensation. They argue, without much explanation, that "[a] constitutional jurisprudence that permitted intervention on behalf of one Thomas but not the other would be unacceptable." 133 Secular claims of conscience are entitled to judicial protection, just as religious claims of conscience. This can be entitled Equal Regard Principle Number Two: it is unacceptable to treat two claimants differently on the sole ground that the motivation for the actions of one is religious and the other nonreligious.

Eisgruber and Sager then posit a third worker, who refuses employment as a replacement worker when the original workers went out on strike. Surprisingly, they balk at extending "equal regard" to this worker. The following is Eisgruber and Sager's explanation:

"Secular Thomas" has the stronger case. Even those who justify military action usually do so only in the face of great anguish and re-

130. 450 U.S. 707 (1981).

131. Eisgruber \& Sager, Vulnerability, supra note 43, at 1292.

132. Id. at 1292-93.

133. Id at 1292. 
gret. The idea of a just war involves high moral stakes and many imponderables. We may accordingly think it reasonable for "Secular Thomas" to build his moral life around absolute pacifist principles, even if we disagree with those principles and even if by doing so Thomas renders himself incapable of complying with certain public norms. . . . Labor law issues have, by contrast, a more economic focus and a less immediate connection to matters of life and death. The stakes are lower and the imponderables less profound. It is possible, but not likely, that we would deem union sympathy to be reasonably constitutive of moral identity in the same way that pacifism is. 134

Does this example violate "equal regard?" No, because the state is entitled to second-guess the "reasonability" of this worker's aversion to strikebreaking. Since the secular believer and the state "in principle share a common epistemic foundation," the state "may legitimately reflect upon and respond to the reasonability of the secular claimant's conscientious commitments."135 Equal regard "does not guarantee that citizens will be able to honor their moral, social, or political commitments without politically imposed costs."136 It would be "fantastic" to treat all conscientious claims in this way. ${ }^{137}$ This idea can be entitled Equal Regard Principle Number Three: the state is not obliged to defer to secular claims of conscience, but may honor them, or not, based on its own assessment of their "reasonability."

To be complete, we should consider a fourth hypothetical: the devout Catholic worker, who out of his understanding of Catholic social thought with its strong commitment to collective bargaining, ${ }^{138}$ refuses to accept employment as a replacement worker. Since this worker possesses a religious conviction, hence a "black box," he would be entitled to unemployment compensation under the Eisgruber-Sager approach (as well as current law).

At this point we can combine each of the results. The religious pacifist receives unemployment benefits (Principle Number One), as well as the secular pacifist (Principle Number Two). The devout Catholic who thinks that being a scab would be sinful would also receive benefits (Principle Number One). The secular labor sympathizer, however, does not receive benefits (Principle Number Three). However, how does this fact effect Principle Number Two? A religiously-motivated refusal to engage in strikebreaking would be treated as eligible for

134. Id. at 1293 .

135. Id. at 1293 .

136. Id. at 1293 .

137. Id. at $1293-94$.

138. See David L. Gregory, Workers' Rights and Catholic Social Teaching, in Christian PerSPECTIVES, supra note 114. 
compensation, while a secular refusal, being insufficiently reasonable, according to Eisgruber and Sager, would not be eligible. If "[a] constitutional jurisprudence that permitted intervention on behalf of one Thomas but not the other would be unacceptable," 139 then why is it acceptable for the Catholic union sympathizer to be protected when the secular union sympathizer is not?

The three parts of the "equal regard" principle are mutually inconsistent. If, as Principle Number Three recognizes, the government must have the latitude to judge the relative weight of secular interests that conflict with governmental objectives, then it is logically impossible to use all such interests as the benchmark for "equal regard." Some secular interests are strong and some are weak. Religious interests cannot be treated equally with respect to both concepts. To treat religious claims as equal to the strongest claims is to privilege them over the weak claims; while treating religious claims as equal to the weaker claims is to disadvantage them compared to the strong.

The only logical alternative is to extend to all secular claims of conscience the same high regard that is extended to religious claims of conscience, without subjecting those claims to an independent examination as to their "reasonability." Eisgruber and Sager rightly reject this solution. There are no conceptual stopping points to this approach:

Need a conscientious commitment be framed in recognizably moral terms? Does it require a system of belief, or can it be simply a sharp impulse? Need it involve an element of sacrifice?.. . [I]f we broaden conscience to include a great swath of the deep commitments people hold, we face the fantastic idea that it is a matter of constitutional regret whenever an otherwise valid law collides with the commitments of an individual or group. ${ }^{140}$

While it is highly desirable for a liberal state to accommodate claims of conscience when it can, Eisgruber and Sager are correct that such a principle cannot be made a matter of constitutional obligation. However, if this idea is true, then it is not possible to maintain both that religious commitments are entitled to constitutional protection and that religious commitments must be treated the same as nonreligious commitments.

Moreover, this problem extends even to contexts in which all the members of the relevant comparison group, the analogs to religion, are treated the same way. In such cases, which Eisgruber and Sager

139. Eisgruber \& Sager, Vulnerability, supra note 43, at 1292.

140. Id. at 1268 . 
call "flat rule cases," 141 one might expect that the principle of "equal regard" would be the same as the rule in Smith. The situation in Smith was a "flat rule" case: the consumption of peyote is illegal no matter what the reason. However, Eisgruber and Sager are not content with this rationale. In principle, they say, the question should be whether the state has failed to "take the deep interests" of religious believers "as seriously as well-recognized secular interests or the interests of adherents to mainstream religions." ${ }^{142}$ In the absence of actual exceptions, that inquiry may proceed on a hypothetical basis, examining close analogies to form an educated guess about how the government would respond if faced with other powerful claims for exemption. At times, these analogies can be rather far afield. For example, when determining whether "equal regard" requires Congress to exempt religiously motivated objectors from the social security system, Eisgruber and Sager claim that the court is required to look at evidence such as the fact that Congress has exempted the ritual use of peyote from controlled substance laws, and has enacted a family leave law to accommodate the burdens of working parents. ${ }^{143}$ In Smith, Eisgruber and Sager argue that the Court should have looked to such statutes such as the exemption of sacramental wine during prohibition. ${ }^{144}$

This example multiplies the problem of indeterminancy that plagued Eisgruber and Sager's theory in the unemployment compensation cases. If we are consulting hypothetical analogies that are not tied to the statutory restriction at hand, we can find some in which the legislature has made accommodations to seemingly minor interests, and some in which the legislature has failed to make accommodations even to seemingly powerful and significant interests. Which extreme shall we choose for our model? If we choose the cases in which the legislature has made accommodations, and accordingly order a religious accommodation, then we will have treated religion better than the less-favored secular analogs. However, if we choose the cases in which the legislature has not made accommodations, and accordingly deny the religious accommodation, we will have afforded religion less than "equal" respect.

141. Id. at 1288.

142. $I d$, at 1289.

143. Eisgruber \& Sager, RFRA, supra note 43 , at 459.

144. Eisgruber \& Sager, Vulnerability, supra note 43, at 1290. Eisgruber and Sager argue that the evidence regarding peyote is "cloudy" and that the Court could reasonably have come out either way. 
In particular, Eisgruber and Sager's proposal seems to suffer the same flaw that they attribute to the RFRA. In order to be constitutional, Eisgruber and Sager argue that the Act must extend protection to "comparably serious secular commitments such as those flowing from parental obligation, philosophical conviction, or lifelong cultural practice." 145 Yet the Eisgruber-Sager approach assumes that all religious commitments are as powerful and worthy of protection as the most powerful and worthy of secular commitments. No secular commitment receives such automatic deference. ${ }^{146}$ To be fair, Eisgruber and Sager maintain that the principle of "equal regard" applies to secular commitments as a matter of legislative responsibility. In other words, the legislature ought to extend "equal regard" to important secular commitments, such as parental obligations, philosophical conviction, and lifelong cultural practice. ${ }^{147}$ However, this idea is not a legally enforceable obligation. Thus, it seems that Eisgruber and Sager's theory "privileges" religion no less than, and in the same way as, the RFRA.

In the end, Eisgruber and Sager refuse to be bound to that the dictum that requires religious concerns to be treated with regard equal to, but not greater than, that which is extended to comparable secular concerns. Under their theory, the right of religious concerns to be treated with "equal regard" is constitutionalized, and thus made a matter of judicial review. The right of secular concerns to be treated with "equal regard," however, is merely precatory. Eisgruber and Sager acknowledge:

Equal regard, of course, is a symmetrical principle, and applies to secular as well as sectarian concerns. But it does not follow that the enforcement of equal regard as it applies to secular conscience is appropriately on the agenda of the judiciary. After all, in principle, Vincent the artist is entitled to have his deep, artistically inspired concerns treated by the state with the same regard as that enjoyed by the deep concerns of citizens generally; but it does not follow that his entitlement should be judicially enforced as an element of constitutional doctrine. ${ }^{148}$

This statement gives the game away. Religious claimants are entitled to bring claims in court whenever they believe that a hypothetical sec-

145. Eisgruber \& Sager, RFRA, supra note 43 , at $453-54$.

146. Eisgruber and Sager admit that "the principle of equal regard as it applies to secular conscience" is not, and should not be, judicially enforceable. Eisgruber \& Sager, Vulnerability, supra note 43, at 1291.

147. For reasons already noted, even as a matter of legislative responsibility, this idea seems incoherent, since it is literally impossible to treat all human commitments equally. The legislature will necessarily consider some commitments more worthy than others.

148. Eisgruber \& Sager, Vulnerability, supra note 43, at 1291. 
ular interest would be sufficiently weighty to compel an accommodation. Nonreligious claimants are entitled to the same regard in theory, but this is not legally enforceable. This idea is very similar to the constitutional doctrine that Eisgruber and Sager are criticizing. A doctrine in which the free exercise of religion is given constitutional protection, and the relative weight given to other important concerns is relegated to the political sphere.

In short, if the state is free to decide how it will treat various secular concerns, but is constitutionally constrained regarding its treatment of religious concerns, there necessarily will be cases in which religion is "singled out." Not all secular concerns will be treated with "equal regard," which means that religious concerns will necessarily be treated better or worse than some secular concerns. "Equal regard" is a logical impossibility in a legal regime in which the government's relation to religion is treated as a matter of constitutional law, whereas the government's relation to the secular analogs to religion is not a constitutional issue. "Equal regard" theory is indeterminate at the core.

\section{A Unified Theory of Religious Freedom}

We have established that the special treatment of religion under the First Amendment is not a form of "privilege," but rather, a comprehensive attempt to minimize government power over religious decisions, whether to benefit or inhibit religion, or control and transform religion. However, it is unclear what approach the courts should take in order to achieve this ideal in a way that interferes as little as possible with the legitimate exercise of democratic authority. In order to resolve this issue, it is necessary to engage in a close analysis of the nature of government action, the ways in which different forms of government action can be abused to exert control or influence over religion, and the relevance of other constitutional norms. The resulting array of doctrinal responses is far from settled, but the following is an outline, in general terms, of the emerging state of constitutional doctrine.

First, let us consider the regulatory authority of the government, its power to command or forbid certain forms of conduct. There are two principal dangers of government control over religious practice: threats to religiously informed conscience and threats to religious institutional autonomy. The former is present when the government takes a normative position contradicting that of a religious group (usually a minority, since it is unusual for democratic governments to pass laws embodying normative positions at odds with the major relig- 
ion of the people). An example would be the law in Smith, forbidding the ingestion of peyote, which is the central sacramental activity of the Native American Church. ${ }^{149}$ The latter is present when the government passes laws that affect a religious institution's choice of leaders or members, its formulation and expression of doctrine, or its internal structure and discipline. Conflicts of this sort are not typically limited to minority religions. Examples would include anti-discrimination laws as applied to clergy selection or historic preservation laws governing a church's symbolic presentation of itself to the world. In both categories, the strategy best calculated to reduce governmental control over religion, while at the same time preserving the government's latitude to exercise the full police power, is to vest an intermediate body (the court) with power to require reasonable accommodation of the religious activity. Under current constitutional interpretation, authority to determine such accommodation in the first instance is primarily legislative.

On the other hand, some exercises of regulatory authority neither clash with religious normative judgments nor invade the institutional autonomy of churches, but rather, merely increase the cost of religiously motivated activity. For example, a speed limit might make it more difficult for a parishioner to attend church. However, such a law should not be subject to heightened scrutiny. The law makes all travel, for all purposes, equally more difficult (or, for that matter, equally safe), with no special effects on religious travel. The burden imposed by this law on religious exercise is not substantial, because the believer can easily (without injury to conscience or disproportionate exertion) achieve his religious purposes without violating the law. The same idea is true of genuinely neutral financial exactions: they may make it more difficult to devote money to religious purposes, but neither cause injury to conscience nor a disproportionate burden on religion. ${ }^{150}$ Where there is no clash of normative values and no disproportionate impact on religious activity, the law should not require, and may not even permit, exceptions for religiously motivated activity. Such laws bear equally on religious and nonreligious activity, and as a result, there is no need to "single out" religion for special treatment.

Second, let us consider the government's power to tax and spend. In this situation, the great dangers arise from the government's discretion to engage in selective subsidy: the power to create incentives for individuals to alter their conduct by providing financial support to one

149. See Smith, 494 U.S. at 872.

150. See Texas Monthly, 489 U.S. 1 (1989). 
choice and not to a substitute. If this discretionary power is the danger, it makes sense to distinguish between two types of governmental spending programs: discretionary grants, and grants made pursuant to neutral, objective formulas. When government officials are accorded the discretion to grant or deny funds based on their judgments about the relative worthiness of competing projects, there are great dangers that the power of the fisc will be used to reward or penalize religious activity. Accordingly, constitutional doctrine has developed to prevent such subsidies from flowing to religious activities (though not to separable secular components of religious institutions). ${ }^{151}$ When subsidies are distributed according to objective, neutral criteria, by contrast, there is no substantial danger that this criteria will create incentives to make particular religious choices. As a result, the Court has approved the constitutionality of aid that is "allocated on the basis of neutral, secular criteria that neither favor nor disfavor religion, and is made available to both religious and secular beneficiaries on a nondiscriminatory basis." 152

Finally, in the context of both regulation and spending, it is necessary to take into consideration other constitutional values that may be at stake in particular cases. A clear example of this idea is religious speech. It is undoubtedly true that speech is a component of religious exercise, however, when a conflict centers on the right of free speech, the proper result is affected by the content and viewpoint neutrality requirements of the Free Speech Clause. Thus, whether religious claimants are seeking special treatment, ${ }^{153}$ or seeking equal access to a public forum or its financial equivalent, ${ }^{154}$ the governing principle will be one of equal treatment, not of accommodation or of separation. Favoring religious speakers over similarly situated nonreligious speakers would violate the viewpoint-neutrality requirement of the Free Speech Clause. ${ }^{155}$

Other constitutional values may lead to similar results. For example, in cases involving the constellation of constitutional values described as "privacy," where the central concern is that aspects of life be

151. See Bowen v. Kendrick; 487 U.S. 589 (1988); Hunt v. McNair, 413 U.S. 734 (1973); Michael W. McConnell, Political and Religious Disestablishment, 1986 BYU L. Rev. 405, 420-24, 434-40, 456-59.

152. Agostini v. Felton, 521 U.S. 203, 231 (1997). Obviously, there are going to be intermediate cases, where grant officials exercise constrained discretion. These will be hard cases.

153. Such cases are unusual in practice. An example would be the claim that a religious speaker is entitled to preferred treatment because the speech is mandated by his religion.

154. See, e.g., Rosenberger v. Rector and Visitors of the University of Virginia, 515 U.S. 819 (1995); Widmar v. Vincent, 454 U.S. 263 (1981).

155. For a more extensive analysis of this issue, see Alan Brownstein, State RFRA Statutes and Freedom of Speech, 32 U.C. DAvIS L. REv. 605 (1999). 
shielded from governmental inquiry or control, it may be necessary to adopt a religion-blind policy. In such contexts, the very attempt to distinguish religious from nonreligious motivations would entail governmental inquiry; it is almost certainly better, and may be constitutionally required, for government to stay out altogether. For example, parents have a privacy right to control the upbringing of their children, and thus (in some contexts) to interpose objections to the intrusions of the state. Within this domain, where the parents are not required to state their reasons, it would follow that religious reasons must be treated no differently than other reasons. This idea can be viewed as a species of "equal regard," but it is more accurately an idea that follows from the values of privacy.

The Supreme Court's emerging jurisprudence, with some exceptions, is increasingly oriented toward protecting religious freedom from government control. With regard to the government's power of imposing burdens on religious exercise through regulation, the Court now generally follows three principles. First, the regulatory power is unconstitutional when it is used to discriminate against religious exercise. ${ }^{156}$ Second, regulation pursuant to neutral and generally applicable laws is generally permissible. ${ }^{157}$ Third, in the discretion of the legislature, religious exercise may be exempted from neutral and generally applicable laws if, but only if, the accommodation is "designed to alleviate government intrusions that might significantly deter adherents of a particular faith from conduct protected by the Free Exercise Clause," 158 and would not "have the effect of 'inducing' religious belief."159

With regard to the government's power to benefit religion through subsidies, there are three similar rules. First, the government may not discriminate in favor of religious recipients. ${ }^{160}$ Second, subsidies distributed pursuant to neutral criteria are generally permissible. ${ }^{161}$ Third, any benefit to religion must occur "only as a result of the genuinely independent and private choices of individuals." 162 This implies that the government may (indeed must) depart from neutrality if, but only if, the neutral scheme does not advance the objective of ensuring that religious judgments are the product of genuinely independent and private choice.

156. Church of the Lukumi Babalu Aye v. City of Hialeah, 508 U.S. 520 (1993).

157. Smith, 494 U.S. at 890.

158. Texas Monthly, 489 U.S. at 18 n.8 (1989).

159. Thomas v. Review Bd., 450 U.S. at 727 (Rehnquist, J., dissenting).

160. Texas Monthly, 489 U.S. at 8.

161. Agostini, 520 U.S. at 234.

162. Id. at 226. 
Thus, whether the government is burdening or benefitting religion, the general principle is the same. Neutral and generally applicable laws are generally permissible, however, special treatment of religion is justified where this would ensure that religious judgments are the result of private judgment. The primary difference is that, after Smith, religious accommodations from regulatory power are mostly left to the legislature, while neutral and generally available subsidy programs are subject to judicial review, under which courts may insist on special treatment of religion when necessary to ensure that private choice prevails.

\section{Using Religious Freedom As A Model}

As discussed above, much of the difficulty of this question is created by the supposed dichotomy between religion and "nonreligion," when in fact religion bears resemblances to, and has differences from, a wide variety of other human concerns.

Religion is a special phenomenon, in part, because it plays such a wide variety of roles in human life: it is an institution, but it is more than that; it is an ideology or worldview, but it is more than that; it is a set of personal loyalties and locus of community, akin to family ties, but it is more than that; it is an aspect of identity, but it is more than that; it provides answers to questions of ultimate reality, and offers a connection to the transcendent; but it is more than that. Religion cannot be reduced to a subset of any larger category. In any particular context, religion may appear to be analogous to some other aspect of human activity - to another institution, worldview, personal loyalty, basis of personal identity, or answer to ultimate and transcendent questions. However, there is no other human phenomenon that combines all of these aspects; if there were such a concept, it would probably be viewed as a religion.

Thus, a rigid insistence that religion be treated the same as "nonreligion," or the same as a secular analog, is pointless and incoherent. There is no single entity that meets the description of "nonreligion" and there will always be more than one secular analog. However, this idea does not mean that religion is always and necessarily sui generis. There are important ways in which the experience of dealing with questions of religious freedom may be applicable to other areas of cultural conflict. Religion was the deepest source of disagreement among the people with which our Founders were familiar. Our Founding society reflected on the problem of religious difference in a deep and serious way, and developed a strategy to enable men and women of diverse commitments to live together peacefully, as free 
and equal citizens, with the least injury to their consciences and convictions, consistent with the necessary purposes of civil government. Rather than treat this solution as an anomaly, or worse yet, to deconstruct it in order to ensure that religion not be accorded a "privileged" status in our society, we should learn from the idea.

The separation of church and state should be a model for separating public from private in other areas. The separation of church and state is not only about church. It is about the idea that the government is not omnicompetent. Government is created by the people for defined and limited ends. The most striking feature of our religious settlement is the adoption of two constitutional proscriptions, which, though in the service of a single objective, look in opposite directions, toward opposite threats. The free exercise principle "singles out" religion for special protection against governmental hostility or interference. The disestablishment principle prevents the government from using its power to promote, advocate, or endorse any particular religious position. These principles balance people's interests in competing, and indeed antithetical, views, and thus achieve a type of neutrality. Rather than assuming this settlement is confined to religion, thus creating the "singling out" problem, it would be helpful to think of religion as the core, or paradigm, for the treatment of other problems of cultural and conscientious conflict, where we wish to guarantee a wide scope for individual and private collective cultural and conscientious diversity, without putting the government in the position of advocating or endorsing any particular orthodoxy.

I do not mean to suggest that doctrines developed for the treatment of religious difference can be mechanically imposed on other areas of cultural conflict. There are differences, which often require differences in treatment. Nor do I mean that courts are entitled to use the Religion Clauses as a basis for overturning democratic judgments outside the field of religion. However, I do mean that the Religion Clauses can be used as a starting point for dealing with other types of difference, as a matter of policy, sometimes of law, and even, occasionally, as a matter of constitutional doctrine under other provisions of the Constitution.

Let us consider several examples of cultural and conscientious conflict in our society. First, the disputes surrounding sexual orientation. ${ }^{163}$ As in the case of religious conflict, these disputes feature a

163. The following is a summary of an argument I present at greater length in Michael W. McConnell, What Would It Mean To Have a "First Amendment" For Sexual Orientation?, in Sexual Orientation \& Human Rights in American Religious Discourse (Saul M. Olyan \& Martha Nussbaum eds., 1998). 
seemingly irreconcilable clash between those who believe that homosexual conduct is immoral and those who believe that it is a natural and morally unobjectionable manifestation of human sexuality. For the most part, our current debates are mutually intolerant: one side seeks to use the force of law to maintain the traditional moral stance against homosexual conduct, while the other wishes to use law to change social attitudes and bring about full social acceptance of homosexuality. An analogy to the Religion Clauses, however, suggests an alternative.

The starting point would be to extend respect to both sides in the conflict of opinion, to treat both the view that homosexuality is a healthy and normal manifestation of human sexuality and the view that homosexuality is unnatural and immoral as conscientious positions, worthy of respect, much as we treat both atheism and faith as worthy of respect. In using the term "respect," I do not mean agreement. Rather, I mean the civil toleration we extend to fellow citizens and fellow human beings even when we disagree with their views. We should recognize that the "Civil Magistrate" is no more "competent a Judge" of the "Truth" about human sexuality than about religion.

Under this approach, the state should not impose a penalty on practices associated with or compelled by any of the various views of homosexuality, and should refrain from using its power to favor, promote, or advance one position over the other. The difference between a "gay rights" position and a "First Amendment" approach is that the former adopts as its governing principle the idea that homosexuality is normal, natural, and morally unobjectionable, while the latter takes the view that the moral issue is not for the government to decide. Thus, the government would not punish sexual acts by consenting gay individuals, nor would it use sexual orientation as a basis for classification or discrimination, without powerful reasons, not grounded in moral objections, for taking such action. On the other hand, the government would not attempt to project this posture of moral neutrality onto the private sphere, but would allow private forces in the culture to determine the ultimate social response. Moreover, the government would not use its power over public schools or other cultural resources to propagate opinion, one way or the other, on the moral question, but would self-consciously leave the business of opinion formation on this matter to the private sphere. Such an approach would produce many of the same advantages for this cultural conflict that the First Amendment produces for religious conflict. This approach would provide the basis for civic peace on an issue where the nation is dangerously divided, it would provide maximum 
respect for individual conscience, it would depoliticize an issue that many of us believe is private and not political in character, and it would help to restore the public-private distinction.

A second sphere of cultural conflict that would bear comparison to the Religion Clauses is that of public support for art, together with attendant controls. In this context, there is no serious question regarding the rights of artists to control their artistic expression, free of government censorship. The issues arise from government subsidies. Congress has established the NEA, which makes grants to various artists and artistic institutions, and has imposed certain restrictions on what kinds of art can be funded. ${ }^{164}$ Spokespersons for the "arts community" typically support the subsidies, but oppose the restrictions on First Amendment grounds.

The analogy to the Religion Clauses would suggest that these two positions are in tension. A program of selective subsidies for artists, based on a government agency's evaluation of artistic merit, necessarily encroaches on artistic freedom. (The effect is magnified by the fact that other donors are said to regard NEA support as an imprimatur of artistic quality.) Imagine the creation and operation of a National Endowment for Religion, which would make grants to clergy and religious institutions on the basis of its evaluation of religious merit. Obviously such a system is incompatible with true artistic (or religious) freedom. Although the courts can interfere to prevent overt viewpoint discrimination, it is not possible, in the context of discretionary grants, to guarantee full artistic freedom.

The only way in which government subsides can be provided to art (or religion) without endangering artistic (or religious) autonomy is through the medium of nondiscretionary programs based on the individual decisions of private actors, such as tax deductible contributions under the tax code or indirect subsidies through private beneficiaries. Otherwise, it is necessary for us to choose between a certain vision of untrammeled artistic freedom and the notion that the government has a strong role to play in selecting and funding worthy art.

A third possible area for analogizing Religion Clauses doctrine to nonreligious analogs concerns freedom of association. Presently, private noncommercial associations enjoy substantial autonomy under the common law of voluntary associations. However, the constitutional protections accorded to such associations appears minimal. Under Roberts $v$. United States Jaycees, ${ }^{165}$ the state is said to have a

164. See National Endowment for the Arts v. Finley, 524 U.S. 569 (1998).

165. 468 U.S. 609 (1984). 
compelling interest in regulating the membership qualifications of such a group. Boy Scouts v. Dale ${ }^{166}$ is a hopeful move in this direction, but the contours of the associational freedom recognized in that decision are not yet clear. In contrast, a religious voluntary association enjoys the freedom to control its own membership and leadership criteria. My suggestion would be to extend the free exercise doctrine more broadly, as a matter of freedom of association. The Jaycees case itself might be an exception; as essentially a business networking organization, the state may have a stronger than usual interest in regulating the Jaycees in order to ensure equal access to economic opportunity. However, most private noncommercial groups should be allowed to constitute and govern themselves.

Other examples in which such analogies might be helpful include: the English-only movement, the use of public schools to engage in nonreligious indoctrination, and the subsidy and governance of political parties. In each of these areas, we should consider the possibility that a civil libertarian regime based on analogy to the Religion Clauses would be superior to the current policy. The Religion Clauses are the most highly articulated doctrinal field devoted to protection of an area of life from governmental control. They are, in a sense, the most classically liberal features of our constitutional tradition. In other areas in which we value pluralism, diversity, and private ordering, we should consider structuring the legal regime on an analogy to the dual protection of free exercise and nonestablishment.

\section{CONClusion}

In a constitutional system that contains a separate provision governing relations between government and "religion," it is inevitable that religion will, at least sometimes, be "singled out" for treatment not accorded nonreligious institutions or activities. Neither the theory of religion-blindness, nor that of "equal regard," can make sense of our constitutional commitment. Both theories posit the treatment of nonreligious commitments as a benchmark for the treatment of religious commitments. However, since the various nonreligious commitments of our society are themselves treated with unequal regard, it is not logically possible to achieve an equality of regard between each secular concept and religion.

Nonetheless, as the most highly articulated constitutional doctrine insulating a sphere of human life from governmental control, the Religion Clauses offer a promising standpoint for constructing and ana- 
lyzing the legal arrangements between government and other aspects of human life that we believe should not be subject to majoritarian control. Rather than insisting that religious concerns receive no more protection than is accorded nonreligious analogs, it may be more helpful to think of ways in which the twin protections of free exercise and nonestablishment could be extended to nonreligious spheres of life. 
[Vol. 50:1 